Preprint of Nagavciuc, V ; Kern, Z ; Ionita, M ; Hartl, C ; Konter, O ; Esper, J ; Popa, I (2020) Climate signals in carbon and oxygen isotope ratios of Pinus cembra tree-ring cellulose from the Călimani Mountains,

Romania. INTERNATIONAL JOURNAL OF CLIMATOLOGY 40: 5 2539-2556.

\title{
Climate signals in carbon and oxygen isotope ratios of Pinus cembra tree-ring cellulose from the Călimani Mountains, Romania
}

Viorica Nagavciuc ${ }^{1,2,3^{*}}$, Zoltán Kern ${ }^{4}$, Monica Ionita ${ }^{5}$, Claudia Hartl ${ }^{6}$, Oliver Konter ${ }^{6}$, Jan Esper $^{6}$, Ionel $\mathrm{Popa}^{7,8}$

${ }^{1}$ Faculty of Forestry, Ștefan cel Mare University, Universității Str. 13, 720229, Suceava, Romania

${ }^{2}$ National Institute for Research and Development of Isotopic and Molecular Technologies, 67-103 Donat Str., 400293 Cluj-Napoca, Romania

${ }^{3}$ Stable Isotope Laboratory, Ștefan cel Mare University, Suceava, Romania

${ }^{4}$ Institute for Geological and Geochemical Research, Research Centre for Astronomy and Earth Sciences, Hungarian Academy of Sciences, Budapest, Hungary

${ }^{5}$ Paleoclimate Dynamics Group, Alfred-Wegener-Institute for Polar and Marine Research, Bussestrasse 24, Bremerhaven, D-27570, Germany

${ }^{6}$ Departement of Geography, Johannes Gutenberg University, Mainz, Germany

${ }^{7}$ National Research and Development Institute for Forestry Marin Dracea, Campulung Moldovenesc, Romania

${ }^{8} \mathrm{INCE}$ - Mountain Economy Center CE-MONT Vatra Dornei, Romania

* Corresponding author Viorica Nagavciuc, nagavciuc.viorica@gmail.com, Ștefan cel Mare University, Suceava, Romania Universității Street 13, Suceava 720229, Romania.

\begin{abstract}
We analyze annually resolved tree-ring stable carbon $\left(\delta^{13} \mathrm{C}\right)$ and oxygen $\left(\delta^{18} \mathrm{O}\right)$ isotopic chronologies from Swiss stone pine (Pinus cembra L.) in Romania. The chronologies cover the period between 1876 and 2012 and integrate data from four individual trees from the Calimani Mts in the eastern Carpathians where climatic records are scarce and starts only from 1961. Calibration trials show that the $\delta^{13} \mathrm{C}$ values correlate with local April-May relative humidity and with regional to larger scale (European) summer precipitation. $\delta^{18} \mathrm{O}$ correlates significantly with local relative humidity, cloud cover, maximum temperature, as well as European scale drought conditions. In all cases, the climate effects on $\delta^{13} \mathrm{C}$ values are weaker than those recorded in the $\delta^{18} \mathrm{O}$ data, with the latter revealing a tendency towards higher (lower) values of $\delta^{18} \mathrm{O}$ during extremely dry (wet) years. The most striking signal, however, is the strong link between the interannual $\delta^{18} \mathrm{O}$ variability recorded in the Calimani Mts and large-scale circulation patterns associated with North Atlantic and Mediteraneean Sea sea surface temperatures. High (low) values of $\delta^{18} \mathrm{O}$ occur in association with a high (low) pressure system over the central and eastern part of Europe and with a significantly warmer (colder) Mediterranean Sea surface temperature. These results demonstrate the possibility of using tree ring oxygen isotopes from the eastern Carpathians to reconstruct regional drought conditions in eastern Europe on long-term time scales and larger scale circulation dynamics over the pre-instrumental periods.
\end{abstract}

Keywords: Swiss stone pine, $\delta^{13} \mathrm{C}, \delta^{18} \mathrm{O}$, Climate response, Dendrochronology, Atmospheric circulation 
Preprint of Nagavciuc, V ; Kern, Z ; lonita, M ; Hartl, C ; Konter, O ; Esper, J ; Popa, I (2020) Climate signals in carbon and oxygen isotope ratios of Pinus cembra tree-ring cellulose from the Călimani Mountains,

Romania. INTERNATIONAL JOURNAL OF CLIMATOLOGY 40: 5 2539-2556.

\section{Introduction}

In terms of recent climate change, when heat waves and summer droughts become more frequent and more intense, the environment and property risks have increased and became more dangerous (IPCC, 2014; Spinoni et al., 2015). As such, the necessity for high precision climate predictions for better adaptation and mitigation has arisen. However, the complex characteristics of present and expected future climate changes can be better understood in the context of past climate variability (IPCC, 2014), due to fact that the trends based on short records are very sensitive to the beginning and end dates and do not, in general, reflect long-term climate trends (IPCC, 2014). In this respect, natural archives have become an important tool to supplement the short available instrumental records. Tree rings are widely used in paleoclimatology because of their annual resolution, precise dating, widespread availability on different parts of the globe, and they have the possibility to create chronologies of thousands of years and to explore climate through different proxies such as: tree-ring width, maximum density and/or stable isotopes (Gagen et al., 2004; Brugnoli et al., 2010; Hughes et al., 2011). Overall, the international Tree-Ring Data Bank (ITRDB) contain more than 4000 records, however most of them are based on the tree-ring width, and only few chronologies are based on the maximum density and even less are based on the variations of stable carbon or oxygen isotopes in tree-ring cellulose (NOAA, 2019).

The carbon and oxygen stable isotope ratios in tree rings incorporate unique information since they record, through isotopic discrimination, plant-specific physiological processes that include climatic effects. The climatic signals registered by stable isotopes are less dependent on the ecoclimatic settings of the sampled trees when compared with tree-ring width and density proxies (Esper et al., 2018). Stable carbon isotope ratios depend on leaf internal concentrations of $\mathrm{CO}_{2}$, which are influenced by the balance between stomatal conductance and the rate of carboxylation during photosynthesis (Farquhar et al., 1989). In dry environments, the ${ }^{13} \mathrm{C} /{ }^{12} \mathrm{C}$ ratio tends to be dominated by stomatal conductance, which is mainly controlled by differences in vapor pressure of the ambient air and the intercellular air spaces within the leaves (Young et al., 2015). In regions without strong moisture stress, the dominant signal recorded by the $\delta^{13} \mathrm{C}$ values is the fluctuation of photosynthetic rate, which is mainly influenced by solar radiation and the production rate of the photosynthetic enzyme RuBisCo (Hafner et al., 2014). Tree-ring $\delta^{18} \mathrm{O}$ is primarily affected by the isotopic ratio of source water and, secondly, by evaporation of leaf water via the stomata which leads to increasing $\delta^{18} \mathrm{O}$ values (Gessler et al., 2014). The isotopic composition of the source water usually mirrors the isotopic composition of precipitation infiltrated into the soil and taken up by the roots (Roden et al., 2000), and depends on the atmospheric circulation patterns and local climate. The evaporation intensity of leaf water depends on the stomatal conductance and the vapor pressure deficit, both of which are directly related to relative humidity (McCarroll and Loader, 2004). Stable isotopes in tree-ring cellulose have proven to be a good proxy in areas where tree-ring width (TRW) and maximum latewood density (MXD) are not strongly controlled by a single climate parameter (Hartl-Meier et al., 2015; Young et al., 2015; Nagavciuc et al., 2019). Oxygen isotopic ratios, in general, lack substantial tree-age effects, rendering statistical de-trending unnecessary, thereby preserving the low frequency inherent to the raw data (Rinne $e t$ al., 2013; Duffy et al., 2017). In addition, climate signals can be reliably detected in carbon and oxygen isotope chronologies comprising lower numbers of replicates (Gagen et al., 2008; Leavitt, 2010) and slight brown-rot decay wood has only a limited influence on the isotopic composition (Nagavciuc et al., 2018). Stable isotopes in tree rings can thus provide representative, accurate and precise information on past 
Preprint of Nagavciuc, V ; Kern, Z ; lonita, M ; Hartl, C ; Konter, O ; Esper, J ; Popa, I (2020) Climate signals in carbon and oxygen isotope ratios of Pinus cembra tree-ring cellulose from the Călimani Mountains,

Romania. INTERNATIONAL JOURNAL OF CLIMATOLOGY 40: 5 2539-2556.

climate variability, where other tree rings proxies fail (Kress et al., 2010; Konter et al., 2014; Cernusak and English, 2015; Hartl-Meier et al., 2015).

Tree-ring carbon and oxygen isotopes records have already been used to reconstruct various climate parameters including temperature (Treydte et al., 2009; Esper et al., 2015), precipitation (Danis et al., 2006; Rinne et al., 2013; Young et al., 2015), drought (Kress et al., 2010; Xu et al., 2014; Labuhn et al., 2016), relative humidity (Haupt et al., 2011), solar radiation (Young et al., 2010) and cloud cover (Gagen et al., 2011), in different parts of the world. There is still a strong contrast between the eastern part of Europe and other regions of the continent because most of the paleoclimatic reconstructions based on tree ring isotopes are distributed from Fennoscandia through western Europe to the Mediterranean region (Treydte et al., 2007; Konter et al., 2014; Young et al., 2015; Labuhn et al., 2016). Thus, by filling the eastern-European gap we would provide a better understanding of past climate variability at the continental scale.

From a climatological point of view, Romania is located in a strategic position, in the eastern part of Europe where the climatic patterns that strongly influence the Atlantic, Mediterranean and Scandinavian regions have convergent influences. Old-growth forests preserved in the Carpathian mountains (Popa, 2016), would allow the construction of very long stable carbon and oxygen isotope chronologies. The high altitude natural forests of the Călimani Mountains, in north-eastern Romania, retain an impressive collection of very old living trees and important deposits of relict wood in excellent states of preservation, covering at least past Millennium (Popa and Kern, 2009).

The aim of this study is to explore the climate signal registered by interannual variability of stable carbon and oxygen isotope ratios in the cellulose of Swiss stone pine tree rings (Pinus cembra L.) from Călimani Mountains, Romania. We statistically analyse the relationship between $\delta^{13} \mathrm{C}$ and $\delta^{18} \mathrm{O}$ and monthly local climate variables over AD1961-2012, gridded climatic data over a longer period (AD1901-2012), and also compare with large-scale circulation patterns. We discuss the skill of the potential climate reconstructions using established statistical calibration and verification tests in order to highlight which climate parameter is most reliably registered by each isotope.

\section{Methods and materials}

\subsection{Study site}

The study area is located in the Călimani Mountains, in the eastern Carpathian Arc (Romania) (Figure 1). A detailed site description can be found in the Popa and Kern, (2009), as both studies are done at the same site. The forest is dominated by Swiss stone pine (Pinus Cembra L.) mixed with Norway spruce (Picea abies Karst., L.) which are replaced by mountain pine (Pinus mugo) towards higher elevations. The study site is characterized by a mountain temperate-continental climate, with severe cold winters and cool summers. The mean temperature ranges from $-6.5^{\circ} \mathrm{C}$ in January to $13.3{ }^{\circ} \mathrm{C}$ in July, while the mean annual precipitation amount is $889 \mathrm{~mm}$, with a summer peak in June to July, for $1961-2012$ period (Figure 1). The geological substrate is composed of the "andesitic arch", represented by the volcanic chain resting on a foundation of shale and Triassic sedimentary formations (Mutihac, 2004). The samples were collected from elevations ranging from $1450 \mathrm{~m}$ a.s.l. to $1850 \mathrm{~m}$ a.s.l. (treeline) while the current timberline is situated at $\sim 1700 \mathrm{~m}$ a.s.l. (Kern and Popa, 2008). Human influence in the study area was limited after 1975 due to the establishment of a Natural Reserve with a high degree of protection. However, a sulfur extraction occurred near to the study site between 1965-1992, with most intense activity during the 1974-1986 period 
Preprint of Nagavciuc, V ; Kern, Z ; Ionita, M ; Hartl, C ; Konter, O ; Esper, J ; Popa, I (2020) Climate signals in carbon and oxygen isotope ratios of Pinus cembra tree-ring cellulose from the Călimani Mountains,

Romania. INTERNATIONAL JOURNAL OF CLIMATOLOGY 40: 5 2539-2556.

127

128

129

130

131

132

133

134

135

136

137

138

139

140

141

142

143

144

145

146

147

148

149

150

151

152

153

154

155

156

157

158

159

160

161

162

163

164

165

166

167

168

(Brânduș and Cristea, 2004) leaving clear signals also in the sulfur concentrations of the wood (Kern et al., 2009).

\subsection{Sample collection, preparation and stable isotope measurements}

Four living trees (labeled Trees 1 to 4) were cored in autumn 2012, using an 11mm Pressler increment borer. Tree ring width (TRW) was measured using LINTAB equipment and TSAP 0.53 software, with $0.001 \mathrm{~mm}$ accuracy. TRW was cross-dated against the local master chronology (Popa and Kern 2009) and checked for missing rings with COFECHA software (Holmes, 1983). The stable isotope analyses were performed for the 1876-2012 period (Table S1). The tree rings were separated with a scalpel ring by ring, and were not pooled prior to the measurements. After that, the $\alpha$-cellulose was extracted using the modified Jayme-Wise method (Loader et al., 1997; Boettger et al., 2007), homogenized by a standard ultrasonic protocol (Laumer et al., 2009) using VCX130 (Sonics \& Materials Inc/USA) device, and dried at $70^{\circ} \mathrm{C}$ for 24 hours.

After being encapsulated in silver, $0.2 \mathrm{mg}( \pm 10 \%)$ of $\alpha$-cellulose was pyrolized over glassy carbon at $1450{ }^{\circ} \mathrm{C}$ and simultaneous measurements of oxygen and carbon isotope ratios $\left(\delta^{13} \mathrm{C}\right.$ and $\left.\delta^{18} \mathrm{O}\right)$ were performed (Leuenberger and Filot, 2007; Loader and Waterhouse, 2014) using a ThermoQuest TCEA interfaced with a Thermo Delta V Advantage IRMS. The isotopic ratios are reported in per mil (\%) relative to the Vienna Standard Mean Ocean Water (VSMOW) for oxygen, and Vienna Pee Dee Belemnite (VPDB) for carbon (Coplen, 1994), respectively, using the traditional $\delta$ (delta) notation. The analytical precision of the measurements was better than $0.2 \%$ for both oxygen and carbon. All samples were measured in triplicates; if their standard deviation exceeded $0.2 \%$, two additional measurements were performed. If one of the five delta vaules was further from the mean of the other four values than their 2 standard deviation that value was considered as outlier and was omitted. The final $\delta^{13} \mathrm{C}$ and $\delta^{18} \mathrm{O}$ values were calculated as the arithmetic mean of the multiple measurements.

\subsection{Correction for non-climatic factors and construction of the dendroisotope chronologies}

The raw carbon isotopic ratios need to be corrected for changes in carbon isotope composition and concentration of atmospheric $\mathrm{CO}_{2}$ due to anthropogenic coal and hydrocarbon combustion from the start of the industrial revolution because these anthtropogenic effects can heavily overprint the climate signals (McCarroll and Loader, 2004; Treydte et al., 2009). To remove the long-term depletion in ${ }^{13} \mathrm{C}$ of the atmospheric $\mathrm{CO}_{2}$, the so-called Suess effect (Keeling, 1979), we applied the correction scheme established for the northern hemispheric variations in atmospheric $\mathrm{CO}_{2}$ isotopic composition based on a compilation of the $\delta^{13} \mathrm{C}$ values of $\mathrm{CO}_{2}\left(\delta^{13} \mathrm{C}_{\mathrm{atm}}\right)$ derived from air inclusions in ice cores (Leuenberger, 2007). Even after the $\delta^{13} \mathrm{C}_{\text {atm }}$ correction, the resulting chronology is still influenced by the increasing values of $\mathrm{pCO}_{2}$ above the pre-industrial level, causing the amount of carbon isotopic fractionation per unit ppm to decrease. This effect was removed following the procedure described by Schubert and Jahren, (2012) (Figure S1).

Several studies have shown that the increase of $\delta^{13} \mathrm{C}$ and $\delta^{18} \mathrm{O}$ values in the juvenile years of tree growth is dependent on the species and the individual tree location (Gagen et al., 2008; Leavitt, 2010; Daux et al., 2011; Xu et al., 2017). The duration of these juvenile trends vary from short periods or non-existent trends (Daux et al., 2011; Kilroy et al., 2016; Duffy et al., 2017) up to 50 years or more than 80 years (Leavitt, 2010). In case of $\delta^{13} \mathrm{C}$, for instance, it can be explained by the fact that young trees, growing close to forest floor or below the canopy, reuse the respired air from the old surrounding trees, which is already 
Preprint of Nagavciuc, V ; Kern, Z ; lonita, M ; Hartl, C ; Konter, O ; Esper, J ; Popa, I (2020) Climate signals in carbon and oxygen isotope ratios of Pinus cembra tree-ring cellulose from the Călimani Mountains,

Romania. INTERNATIONAL JOURNAL OF CLIMATOLOGY 40: 5 2539-2556. depleted in ${ }^{13} \mathrm{C}$ (Treydte et al., 2009). In order to examine the juvenile trends of $\delta^{13} \mathrm{C}$ and $\delta^{18} \mathrm{O}$ ratios in treering cellulose, the Trees 1,2 and 3 were aligned by cambial age and the corresponding anomalies were calculated (Figure S2 and S3). Tree 4 was not taken into account because the first 198 years from the pith were not analyzed yet and the remaining data falls outside the juvenile lifespan.

The negative exponential curve (neg) detrending method was applied using the ARSTAN software (Cook and Peters, 1981; Cook, 1985;). The final $\delta^{13} \mathrm{C}_{\text {res }}$ chronology was developed by: 1) inverting the $\delta^{13} \mathrm{C}$ (corrected for changes in carbon isotope composition and concentration of atmospheric $\mathrm{CO}_{2}$ ) by multiplying the individual series with (-1), in order to have positive values and 2) by removing the $\delta^{13} \mathrm{C}$ age trend by calculation of residual values from a negative exponential function (Esper et al., 2015); and 3) calculation of the robust means of the detrended $\delta^{13} \mathrm{C}$ series, 4) inverting the resulting $\delta^{13} \mathrm{C}$ chronology by multiplying with (-1) in order to have the original trend of chronology, which was used further for climate correlations.

The robustness of the obtained mean chronology was assessed by Expressed Population Signal (EPS) and the inter-series correlation (Rbar). EPS is a measure of how well the available finite sample of tree-ring data represents an infinite population chronology (Wigley et al., 1984; Buras, 2017). EPS and Rbar values were calculated for detrended $\delta^{13} \mathrm{C}$ series and for raw $\delta^{18} \mathrm{O}$ series for the $1876-2012$ period, with a running window of 50 years with an overlap of 25 years.

\subsection{Climate data and statistical methods}

The linear relationship between the tree-ring $\delta^{13} \mathrm{C}_{\text {res }}$ and $\delta^{18} \mathrm{O}$ records and cloud cover (CLD), precipitation amount $(\mathrm{PP})$, relative humidity $(\mathrm{RH})$, mean, maximum and minimum temperature (Tm, Tx, and $\mathrm{Tn}$ ) were analyzed using ROCADA gridded data for the nearest grid point to the study site (Dumitrescu and Birsan, 2015) with a resolution of $0.1^{\circ} \times 0.1^{\circ}$ for the period 1961-2012. Given that the plant physiological processes regulating the isotopic fractionation are sensitive to precipitation and temperature, we also tested the relationship with the drought index as it integrates these two parameters (Bégin et al., 2015). For this, we analyzed the relationship with a climate index (CI) as well as with the Standardized Precipitation-Evapotranspiration Index (SPEI). The CI index is computed by subtracting the standardized temperature from the standardized precipitation. Thus, negative values of CI indicate dry and/or warm conditions, whereas positive values of CI indicate wet and/or cold conditions. To calculate the Standardized Precipitation-Evapotranspiration Index (SPEI) we used monthly precipitation totals, $2 \mathrm{~m}$ surface air temperature means and potential evapotranspiration. Since the study site is not known to exhibit long-term dry spells, we focus on short-term drought and wetness variability, by calculating SPEI for 3 months of accumulation period (SPEI3 from now on) (Beguería et al., 2014).

To have a longer term perspective of the relationship between the tree-ring parameters and climate variables, the PP and CLD over the closest grid points near the study site were obtained from the monthly CRU T.S. 4.01 dataset for the 1901-2012 CE period (Harris et al., 2014), with a spatial resolution of $0.5^{\circ}$ $\times 0.5^{\circ}$. Also, CI and SPEI3 indices were calculated basis on data from the CRU T.S. 4.01 climate dataset.

To investigate the link with the large-scale atmospheric circulation patterns we used the seasonal means of Geopotential Height at 500 milibar (mb) (Z500), zonal wind (U500) and meridional wind (V500) at $500 \mathrm{mb}$ from the Twentieth Century Reanalysis (V2) data set (Whitaker et al. 2004; Compo et al. 2006, 2011) on a $2^{\circ} \times 2^{\circ}$ grid, over the $1876-2012$ CE period. For sea surface temperature (SST) we used the $1^{\circ}$ $\times 1^{\circ}$ Hadley Centre Sea Ice and Sea Surface Temperature data set-HadISST (Rayner et al., 2003). These data sets have a global coverage. 
Linear correlations between $\delta^{13} \mathrm{C}_{\text {res }}$ and $\delta^{18} \mathrm{O}$ values and monthly or seasonal climate parameters (Zang and Biondi, 2015) in the R environment (R Development Core Team, 2014). To identify connections with the large-scale atmospheric circulation and the North Atlantic Ocean SST, we constructed the composite maps of Z500 and SST standardized anomalies for the summer season by selecting the years when the value of the normalized dendroisotope time series was $>1$ standard deviation (High) and $<-1$ standard deviation (Low), respectively. This threshold was chosen as a compromise between the strength of the climate anomalies associated with $\delta^{13} \mathrm{C}_{\text {res }}\left(\delta^{18} \mathrm{O}\right.$, respectively) anomalies and the number of maps that satisfy this criterion. Further analysis has shown that the results are not sensitive to the exact threshold value used for the composite analysis (not shown). The significance of the composite maps is based on a standard t-test (confidence level $95 \%$ ).

The calibration and verification model was analyzed using the R packages dplR (Bunn, 2008) and treeclim (Zang and Biondi, 2015). Three statistical tests were performed to evaluate the strength of the calibration model: the Reduction of Error (RE), the Coefficient of Efficiency (CE) and the Durbin-Watson Test (DW), in the split window approach (Cook et al., 1994). The calibration/verification model with meteorological data was performed by splitting in forward and reverse periods. For the short local climate data, a calibration length of $75 \%$ of the chronology was used, and for the longer gridded data $50 \%$.

\subsection{Stability maps}

To test the stability of the relationship between the dendroisotope records and climate variables we make use of stability maps, a methodology successfully used in the seasonal forecast of the European rivers and Antarctic sea ice to examine the stationarity of the long-term relationship between our proxies and the gridded climate data (Ionita et al., 2008, 2014, 2018). In order to detect stable predictors, the variability of the correlation between the tree-ring parameters and the gridded data is investigated within a 31-year moving window over the $1901-2012$ period. The correlation is considered stable for those regions where the tree-ring parameter and the gridded data are significantly correlated at the $90 \%$ or $80 \%$ level for more than $80 \%$ of the moving window. A detailed description of the methodology is given by Ionita (2017). The basic idea of this methodology is to identify regions with stable correlations (meaning the correlation does not change over time) between $\delta^{13} \mathrm{C}_{\text {res}}, \delta^{18} \mathrm{O}$ and gridded data (e.g. PP, CI and SPEI3) with different time lags.

\section{Results and discussion}

\subsection{Characteristics of the carbon and oxygen isotope chronologies}

The mean of the combined chronology of $\delta^{13} \mathrm{C}$ raw values is $-22.3 \%$ and the data vary between $23.5 \%$ and $-20.9 \%$. Lag 1 and Lag 2 autocorrelations of the $\delta^{13} \mathrm{C}$ data are high $(\mathrm{r}=0.78$ and $\mathrm{r}=0.68)$. Such a high autocorrelation can be explained by the accentuated trend of the chronology. A high autocorrelation can be expected as the trees store the glucose assimilated in the late autumn and winter, and use it in the next spring when a new ring starts growing (Pallardy, 2008; Kimak and Leuenberger, 2015).

The detrended data of trees 1, 2 and 3 which have similar ages (around 130 years), show a negative slope of approximately $1.5-2 \%$, while Tree 4 (representing >300 years cambial age) does not show any trend for the analyzed period, indirectly supporting the absence of age-related trends in $\delta^{13} \mathrm{C}$ data with a cambial age of 100 years and older (Gagen et al., 2008). The inter-series correlation $(\mathrm{Rbar}=0.45)$ and 
Preprint of Nagavciuc, V ; Kern, Z ; lonita, M ; Hartl, C ; Konter, O ; Esper, J ; Popa, I (2020) Climate signals in carbon and oxygen isotope ratios of Pinus cembra tree-ring cellulose from the Călimani Mountains,

Romania. INTERNATIONAL JOURNAL OF CLIMATOLOGY 40: 5 2539-2556.

253 Expressed Population Signal $(\mathrm{EPS}=0.75)$ reveal an acceptable internal coherence but low confidence of 254 the site chronology.

The $\delta^{18} \mathrm{O}$ values of the combined chronology vary around the mean of $29.3 \%$, ranging from $27.6 \%$ to $31.5 \%$. The $\delta^{18} \mathrm{O}$ chronology is characterized by low autocorrelation $(\mathrm{r}=0.28$ and $\mathrm{r}=0.05$ on the Lag 1 and Lag 2, respectively), which indicates that previous year conditions do not have a strong effect on oxygen isotopic variability in tree-ring cellulose, indicating that the source water originates mainly from the current season rainfall (McCarroll and Loader, 2004). The $\delta^{18} \mathrm{O}$ series show no juvenile effects or common increasing or decreasing trends in the first 140 years of tree age (Figure $2 b$ and Figure S3). Therefore, we conclude that $\delta^{18} \mathrm{O}$ values from Swiss Stone pine tree-ring cellulose from Calimani Mts can be used for dendroclimatological studies without any detrending procedure. The mean inter-series correlation $(\mathrm{Rbar}=$ 0.77 ) and Expressed Population Signal (EPS $=0.92$ ) demonstrate the robustness of the $\delta^{18} \mathrm{O}$ chronology and indicate that the $\delta^{18} \mathrm{O}$ values display a high amount of shared variance originating from a common controlling factor related to climatic conditions.

\section{$3.2 \delta^{13} \mathrm{C}$ and $\delta^{18} \mathrm{O}$ climate response on local scale}

Detrended carbon isotopic data from Călimani Mts correlate significantly with June to August (JJA) precipitation $(r=-0.49, \mathrm{p}<0.05)$, with March and April RH $(\mathrm{r}=0.43$ and $\mathrm{r}=0.45$, respectively, $\mathrm{p}<0.05)$ and with July and August SPEI3 ( $\mathrm{r}=-0.45$ and $\mathrm{r}=-0.52$, respectively, $\mathrm{p}<0.05$ ) (Table 1). No significant correlation was found between $\delta^{13} \mathrm{C}_{\text {res }}$ and temperature (Table 1). The sampled trees are located at high elevation, where a thick layer of snow cover accumulates during the winter. The resulting water from snowmelt, starting in March-April, infiltrates in the highly permeable soil, which allows the retention of soil water. Thus, the derived spring soil moisture content together with summer precipitation amounts become the most important factors which controlling the carbon isotopic composition in tree-ring cellulose (McCarroll and Loader, 2004). The RH in spring is related to high precipitation and snowmelt, which contribute to supplement the soil moisture and water aquifers. When tree rings start to grow, water availability in soil and high RH leads to high stomatal conductance, leading to low $\delta^{13} \mathrm{C}$ values because of strong ${ }^{13} \mathrm{C}$ discrimination (McCarroll and Loader, 2004; Loader et al., 2008).

However, the split-period calibration model shows very poor statistical reconstruction skills (Table S2 and S3). This, as well as the relatively low signal-strength statistics of the mean chronology (see section 3.1) underlines that a robust and reliable reconstruction is still not achieveable based on carbon isotopes in Călimani Mountains. These results might be hindered by the low replication (four trees). Nevertheless, by using more replicates a robust and reliable reconstruction might be achievable.

The stable oxygen isotope chronology shows a high correlation with the local climate parameters during the summer months (June, July and August) (Table 2) which is also in agreement with the commonly reported signal in European tree sites (Treydte et al., 2007; Saurer et al., 2008; Hartl-Meier et al., 2015). The $\delta^{18} \mathrm{O}$ values are negatively correlated with the precipitation $(\mathrm{r}=-0.55, \mathrm{p}<0.05)$, CLD $(\mathrm{r}=-0.67, \mathrm{p}<$ $0.05)$, RH $(r=-0.64, p<0.05)$ and CI $(r=-0.69, p<0.05)$; and positively correlated with the Tx $(r=0.60)$ in JJA (Table 2). The high correlation with CLD and RH can be related to the high correlation between these two climatic parameters $(\mathrm{r}=0.75, \mathrm{p}<0.05)$. Relative humidity has a direct effect on leaf transpiration rate and stomatal conductance through the ratio of vapor pressure inside to that outside of the leaf (McCarroll and Loader, 2004). The low RH determines an increase of leaf transpiration rates, causing a high intensity of stomatal conductance. Thereby, evaporation through the open stomata enriches the isotopic composition of leaf water which is transferred to photosynthate (sucrose) and effectively transferred to tree- 
Preprint of Nagavciuc, V ; Kern, Z ; lonita, M ; Hartl, C ; Konter, O ; Esper, J ; Popa, I (2020) Climate signals in carbon and oxygen isotope ratios of Pinus cembra tree-ring cellulose from the Călimani Mountains,

Romania. INTERNATIONAL JOURNAL OF CLIMATOLOGY 40: 5 2539-2556.

ring cellulose (Gessler et al., 2014). A similar direct link between cloud cover and stable isotopes in plant water is not known so, despite the slightly lower correlation coefficient, RH is considered as the actually most influential environmental parameter regulating interannual $\delta^{18} \mathrm{O}$ variability of cellulose in stone pine tree rings in the Calimani Mts.

\subsection{Asymmetric signal in high and low extreme proxy years}

The comparison between extreme values of $\delta^{13} \mathrm{C}_{\text {res }}$ and $\delta^{18} \mathrm{O}$ and the seasonal cycle for precipitation and relative humidity for the instrumental period $1961-2012$ shows interesting patterns. Years recording the highest ( $>1$ standard deviation) and lowest $\left(<-1\right.$ standard deviation) values for $\delta^{13} C_{\text {res }}$ (Figure 3a) and $\delta^{18} \mathrm{O}$ (Figure 3b) were selected and used to calculate the seasonal cycle in precipitation (Figure $3 \mathrm{c}$ and $3 \mathrm{~d}$ ) and relative humidity (Figure $3 \mathrm{e}$ and $3 \mathrm{f}$ ). Extreme low values of $\delta^{13} \mathrm{C}$ and $\delta^{18} \mathrm{O}$ are connected to wetter conditions than average from May until August (Figure $3 \mathrm{c}$ and $3 \mathrm{~d}$ ). In contrast, drier conditions are detected in June - August in association with high $\delta^{13} \mathrm{C}$ and in May - August in association with high $\delta^{18} \mathrm{O}$ values. In the case of RH, the differences in the seasonal cycle are not so obvious for extreme $\delta^{13} \mathrm{C}_{\text {res, }}$, whereas for extreme $\delta^{18} \mathrm{O}$ years, there is a clear and distinct seasonal cycle (Figure $3 \mathrm{e}$ and $3 \mathrm{f}$ ). More humid conditions than average, are detected from June to September associated with extreme low values of $\delta^{18} \mathrm{O}$, while less humid conditions than average are detected from April to September accompanied by high values of $\delta^{18} \mathrm{O}$. The differences in the seasonal cycle of precipitation are captured more clearly by $\delta^{13} \mathrm{C}_{\text {res }}$ extreme years compared to $\delta^{18} \mathrm{O}$. Based on these relationships we can argue that the seasonal distribution of precipitation amount acts as a limiting factor for $\delta^{13} \mathrm{C}_{\text {res }}$ extreme values, whereas the seasonal cycle of RH acts to strongly influence the $\delta^{18} \mathrm{O}$ extreme values, especially in the case of high $\delta^{18} \mathrm{O}$. The seasonal cycle analysis indicates that months with deviations from average climatic conditions differ between the years characterized by low or high values in the proxy data, especially in the case of $\mathrm{RH}$ for extreme $\delta^{18} \mathrm{O}$ years.

\subsection{Spatial correlation with climate data}

Several studies have detected a loss of climate sensitivity in ring-width (Jacoby et al., 2000; Esper et al., 2010) and density (Briffa et al., 2004) chronologies, especially at high latitudes, as well as for several species at the upper treeline in the European Alps (Carrer and Urbinati, 2006; Leonelli et al., 2009). Ocassionally, unstable correlations have been found also for stable isotopes (Treydte et al., 2007; Bale et al., 2010). In this respect, a stable relationship over time between tree-ring proxies and climate variables is crucial for climate reconstructions. In order to test the strength of the relationship between our proxy data and gridded data, at European level, we have applied a methodology, the so-called stability maps, successfully used for the monthly and seasonal prediction of streamflow for central European Rivers (Ionita et al., 2012, 2014).

The stability map between $\delta^{13} \mathrm{C}_{\text {res }}$ and PP and SPEI3 (Figures S4 and S5), shows no stable and significant correlations are found over the period 1902 - 2012, at European level, although for the period 1961 - 2012 significant correlations with local data have been found between $\delta^{13} \mathrm{C}_{\text {res }}$ and PP and SPEI3 for summer months (Table 1). This indicates that the relationship between the available $\delta^{13} \mathrm{C}_{\text {res }}$ data and the climate drivers is non-stationary in time. A higher replication might help to improve the potential climate signal and make the stable carbon isotope dataset of Calimani Stone pine tree rings suitable for paleoclimatological purposes. 
Preprint of Nagavciuc, V ; Kern, Z ; lonita, M ; Hartl, C ; Konter, O ; Esper, J ; Popa, I (2020) Climate signals in carbon and oxygen isotope ratios of Pinus cembra tree-ring cellulose from the Călimani Mountains,

Romania. INTERNATIONAL JOURNAL OF CLIMATOLOGY 40: 5 2539-2556.

For $\delta^{18} \mathrm{O}$ we have computed the stability maps with the gridded data for CI and SPEI3. The stability map between $\delta^{18} \mathrm{O}$ and SPEI3 (Figure 4), with different time lags, indicates that stable and significant correlations persist from June until September. Significant, stable and negative correlations are observed over the eastern part of Europe (e.g. Romania, Serbia, Bulgaria and Ukraine), while significant, stable and positive correlations are observed over Fennoscandia (e.g. Norway, Sweden and the western part of Finland). This dipole-like structure (opposite correlations over Fennoscandia and the eastern part of Europe) in the spatial correlation with SPEI3 gridded data, is a common feature of drought occurrence at European level (Ionita, 2015). The spatial extent of the correlation is largest for August SPEI3. The stability maps between $\delta^{18} \mathrm{O}$ and $\mathrm{CI}$ (Figure 5) shows that stable and significant correlations are observed throughout the summer months (June to August) and the spatial extent of the correlations is also characterized by a dipolelike structure, similar to the one obtained for SPEI3. The largest spatial extent of the stable correlations is found when CI is averaged throughout the summer months (JJA). Based on the results obtained from the stability maps, we can argue that $\delta^{18} \mathrm{O}$ values of the Calimani stone pine isotope record reveal both local as well as European scale climate variability. Overall, during summer, high $\delta^{18} \mathrm{O}$ values are associated with dry conditions and positive temperature anomalies over the central, southeast and eastern Europe, while low $\delta^{18} \mathrm{O}$ values are associated with negative temperature anomalies and wet summers over the eastern part of Europe (Figure 4 and Figure 5). The dry and warm climatic conditions determine the increase of ambient/intercellular vapor pressure gradient, causing enrichment of ${ }^{18} \mathrm{O}$ in the leaf water which is them transferred to the tree ring cellulose (Roden et al., 2000; McCarroll and Loader, 2004).

Based on the results from the stability maps (Figure 4 and Figure 5), we have defined two indices, one for August SPEI3 and one for JJA CI, by averaging the gridded data sets over the region $\left(22^{\circ} \mathrm{E}-30^{\circ} \mathrm{E}\right.$, $\left.45^{\circ} \mathrm{N}-50^{\circ} \mathrm{N}\right)$ for August SPEI3 and over the region $\left(23^{\circ} \mathrm{E}-30^{\circ} \mathrm{E}, 43.5^{\circ} \mathrm{N}-50^{\circ} \mathrm{N}\right)$ for JJA CI. We choose these particular regions, because significant and stable correlations are found over these two areas and they are located in the vicinity of our studied forest. In order to verify the reconstruction skill for these two indices, the calibration-verification model was performed for both SPEI3 and CI (Figure 6a and 6b). The positive and significant values for SPEI3 (CI) of RE $=0.58(0.59), \mathrm{CE}=0.54(0.58)$, and the significant correlation coefficients indicate that the regression model provides predictive skill for reconstruction (Cook et al., 1994) while the Durbin-Watson statistics (2.28 for SPEI3, 1.80 for CI) do not suggest any linear trend in the model residuals (Table S4 - SPEI3 and Table S5 - CI). This temporally stable relationship between $\delta^{18} \mathrm{O}$ and SPEI3 (CI) was also tested by applying the stability maps methodology (Figure 4 and Figure 5). Overall, the best verification result was obtained for CI (Table S5), indicating the robustness of the regression model. This shows that the $\mathrm{CI}$ model based on $\delta^{18} \mathrm{O}$ is significantly related to the actual variation of dry - warm/wet - cold climatic conditions over the eastern part of Europe, including the study area.

The seasonal cycle of August SPEI3 (CI) (Figure 6c (6d)) associated with extreme values of $\delta^{18} \mathrm{O}$ (Table S6, Figure 3) over the period 1902 - 2012 show that wetter conditions than average are detected from March until September by extreme low values of $\delta^{18} \mathrm{O}$ (Figu67re 6c), whereas drier conditions are recorded from January to September for extreme high values of $\delta^{18} \mathrm{O}$ (Figure 6c). The highest differences in the amplitude of the seasonal cycle of SPEI3 are recorded from June to August. Combined wetter and colder conditions than average are observed from May until August for the years characterized by low values of $\delta^{18} \mathrm{O}$ (Figure 6d), whereas drier and warmer conditions than average are observed from January until August for extreme high $\delta^{18} \mathrm{O}$ values (Figure 6d). The seasonal cycle analysis indicates that there is a clear change in the absolute values of the analyzed variables (SPEI3 and CI) through the year for extreme 
Preprint of Nagavciuc, V ; Kern, Z ; lonita, M ; Hartl, C ; Konter, O ; Esper, J ; Popa, I (2020) Climate signals in carbon and oxygen isotope ratios of Pinus cembra tree-ring cellulose from the Călimani Mountains,

Romania. INTERNATIONAL JOURNAL OF CLIMATOLOGY 40: 5 2539-2556.

$\delta^{18} \mathrm{O}$ values. For example, the value of $\mathrm{CI}$ in June and July for extreme low years is more than double compared to the ones recorded during years with extreme high $\delta^{18} \mathrm{O}$ values. This verifies that the $\delta^{18} \mathrm{O}$ in tree rings is able to properly capture the occurrence of extreme summers in terms of SPEI3 and CI.

\subsection{Large-scale atmospheric circulation}

To investigate the relationship between the inter-annual variability of $\delta^{18} \mathrm{O}$ values in tree rings from Calimani Mts. and large-scale atmospheric circulation composite maps of the geopotential height at 500mb (Z500) and SST for high (> 1 standard deviation) and low (<-1 standard deviation) $\delta^{18} \mathrm{O}$ values for the summer months (JJA) were generated (Figure 7). Because, $\delta^{18} \mathrm{O}$ records from Swiss stone pine reflects very well the drought conditions at European scale, it is fair to argue that $\delta^{18} \mathrm{O}$ can partially reflect also the prevailing large-scale circulation (e.g. Rossby waves, atmospheric blocking) and the variability of the North Atlantic Ocean SST (Ionita et al., 2012, 2017; Schubert et al., 2014; Kingston et al., 2015; Spinoni et al., 2015). High values of $\delta^{18} \mathrm{O}$ are associated with a high-pressure system over southern and central Europe and the Mediterranean Sea, and with a low-pressure over the northern Atlantic Ocean, northern Europe and Russia, which are linked to Rossby-wave oscillations (Ionita et al., 2012, 2017; Van Lanen et al., 2016) (Figure 7a). This pattern favors the advection of dry and warm air from the northern part of Africa towards the south-eastern part of Europe (including the study site). In contrast to this, low values of $\delta^{18} \mathrm{O}$ are associated with a low-pressure center over central and eastern part of Europe and a high-pressure system over the northern Atlantic Ocean, Western and northern Europe (Figure 7b). The negative Z500 anomalies centred over the central and eastern part of Europe are consistent with enhanced precipitation over this region and the advection of moist air from the Mediterranean region towards Romania (the wind vectors in Figure 7b). A similar large-scale pattern has been found to be associated with enhanced summer precipitation and high streamflow anolmalies over Romania, including our study region (Ionita et al., 2015). Throughout the summer period, the high-pressure centers are associated with anticyclonic circulation, which generates heat waves and droughts, while the low-pressure centers are associated with cyclonic circulation thus generates wet summers (Ionita et al., 2012).

Significant and stationary spatial correlations were found between $\delta^{18} \mathrm{O}$ and CI and SPEI3 at European level (Figure 4 and Figure 5). In Figure 7c and Figure 7d, we further examined the relationship between $\delta^{18} \mathrm{O}$ and oceanic conditions, because the occurrence of droughts and heat waves over the European region is significantly affected by adjacent oceanic condition on yearly to decadal time scales (Cassou $e t$ al., 2005; Della-Marta et al., 2007; Schubert et al., 2014; Ionita et al., 2017). The role of the North Atlantic Ocean and Mediterranean Sea SST in triggering extreme drought at European level has been demonstrated by previous studies (Feudale and Shukla, 2011; Ionita et al., 2012, 2017; Kingston et al., 2013; Ionita, 2015). Following this line, significant correlations between $\delta^{18} \mathrm{O}$ values and North Atlantic Ocean SST indicate possible connections between the moisture availability over the eastern part of Europe and remote ocean areas. The high $\delta^{18} \mathrm{O}$ values correspond to the positive SST anomalies over the Mediterranean Sea and the northern Atlantic Ocean and negative SST anomalies over the southern Atlantic Ocean (Figure 7c). In contrast, the low $\delta^{18} \mathrm{O}$ values correspond to negative SST anomalies over the Mediterranean Sea and the Black Sea and positive SST anomalies over the Atlantic Ocean (Figure 7d). Overall, the structure of the SST anomalies in Figure 7 resembles the SST anomalies responsible for the occurrence of extreme drought events over the southern and eastern part of Europe (e.g. 2003, 2015) (Van Lanen et al., 2016; Ionita et al., 2017). In a recent paper, Ionita et al., (2017) have shown that warm Mediterranean SSTs have preceded and 
Preprint of Nagavciuc, V ; Kern, Z ; Ionita, M ; Hartl, C ; Konter, O ; Esper, J ; Popa, I (2020) Climate signals in carbon and oxygen isotope ratios of Pinus cembra tree-ring cellulose from the Călimani Mountains,

Romania. INTERNATIONAL JOURNAL OF CLIMATOLOGY 40: 5 2539-2556.

occurred concurrently with dry summers over most of the central and eastern part of Europe. Moreover, the SST anomalies associated with high/low values of $\delta^{18} \mathrm{O}$ over our analyzed region are similar to the SST anomalies associated with $\delta^{18} \mathrm{O}$ extreme values recorded by latewood cellulose of oak (Quercus robur L.) trees growing in the NW part of Romania (Nagavciuc et al., 2019).

\section{Conclusions and perspectives}

Although tree-ring based carbon and oxygen isotope records have been extensively used to reconstruct various climate paramaters at European scale (Treydte et al., 2009; Esper et al., 2015; Kress et al., 2010), currently there is a lack of such studies over the eastern part of Europe, including Romania. Thus, in this study we have analyzed the climate signal registered by stable carbon and oxygen isotopes ratios in the cellulose of Swiss stone pine tree rings from Calimani Mountains, Romania. Stable oxygen isotope ratio in Swiss stone pine tree ring cellulose from Calimani Mountains represents a better indicator for dendroclimatological application than the stable carbon isotope ratio. The correlation of all climatic parameters is higher and temporally more stable with $\delta^{18} \mathrm{O}$ than with $\delta^{13} \mathrm{C}$. The poor statistical skill for carbon as a proxy for paleoclimate reconstructions as well as the relatively low signal-strength statistics of the mean carbon chronology underlines that reliable reconstruction is still not achievable based on carbon isotopes in Călimani Mountains. These results might be hindered by the low replication (four trees). Nevertheless, by using more replicates a robust and reliable reconstruction might be achievable.

For $\delta^{18} \mathrm{O}$ values, the calibration and verification results demonstrate that $\delta^{18} \mathrm{O}$ is correlated with local summer relative humidity, cloud cover, maximum temperature, as well as the drought conditions at a European scale. The highest correlation coefficients and best statistical skills were obtained for $\delta^{18} \mathrm{O}$ values and relative humidity at local scale, and $\delta^{18} \mathrm{O}$ and SPEI3 and CI at European scale. As such, this calibration could be used to provide a long record of summer drought conditions over the eastern part of Europe.

At interannual time-scales, the variability of $\delta^{18} \mathrm{O}$ reflects changes in the large-scale atmospheric circulation and the sea surface temperature from the North Atlantic Ocean and the Mediterranean Sea. High values of $\delta^{18} \mathrm{O}$ are associated with an extended atmospheric blocking over the central and eastern part of Europe and a warm Mediterranean Sea and a cold central Atlantic Ocean. This kind of prevailing largescale atmospheric circulation (e.g. anticyclone over the central and eastern part of Europe and cold central north Atlantic Ocean and warm Mediterranean Sea) is usually associated with extreme droughts and heatwaves over the central and eastern part of Europe (Van Lanen et al., 2016; Ionita et al., 2017).

Stable oxygen isotope composition of Swiss stone pine tree ring cellulose from northeastern Romania represents a great potential for long paleoclimatic reconstructions. Such records offer the opportunity to reconstruct both regional drought and large-scale circulation variability over southern and central Europe and allows us to fill the gap, over the eastern part of Europe, in order to be able to better understand past climatic variability at continental scale.

\section{Acknowledgements}

The research leading to these results has received funding from EEA Financial Mechanism 2009 - 2014 under the project contract no CLIMFOR18SEE. PI was supported partial by the project number PN-III-P4ID-PCE-2016-0253. VN was supported partial by German Federal Environmental Foundation (DBU). MI was funded by the Helmholtz Climate Initiative - REKLIM. 
Preprint of Nagavciuc, V ; Kern, Z ; Ionita, M ; Hartl, C ; Konter, O ; Esper, J ; Popa, I (2020) Climate signals in carbon and oxygen isotope ratios of Pinus cembra tree-ring cellulose from the Călimani Mountains,

Romania. INTERNATIONAL JOURNAL OF CLIMATOLOGY 40: 5 2539-2556.

462

463

464

465

466

467

468

469

470

471

472

473

474

475

476

477

478

479

480

481

482

483

484

485

486

487

488

489

490

491

492

493

494

495

496

497

498

499

500

501

502

503

\section{References}

Bale RJ, Robertson I, Leavitt SW, Loader NJ, Harlan TP, Gagen M, Young GHF, Csank AZ, Froyd CA, McCarroll D. 2010. Temporal stability in bristlecone pine tree-ring stable oxygen isotope chronologies over the last two centuries. Holocene, 20(1): 3-6. https://doi.org/http://dx.doi.org/10.1177/0959683609348867.

Bégin C, Gingras M, Savard MM, Marion J, Nicault A, Bégin Y. 2015. Assessing tree-ring carbon and oxygen stable isotopes for climate reconstruction in the Canadian northeastern boreal forest. Palaeogeography, Palaeoclimatology, Palaeoecology. Elsevier B.V., 423: 91-101. https://doi.org/10.1016/j.palaeo.2015.01.021.

Beguería S, Vicente-Serrano SM, Reig F, Latorre B. 2014. Standardized precipitation evapotranspiration index (SPEI) revisited: Parameter fitting, evapotranspiration models, tools, datasets and drought monitoring. International Journal of Climatology, 34(10): 3001-3023. https://doi.org/10.1002/joc.3887.

Boettger T, Haupt M, Knller K, Weise SM, Waterhouse JS, Rinne T, Loader NJ, Sonninen E, Jungner H, Masson-delmotte V, Guillemin M, Pierre M, Pazdur A, Leuenberger M, Filot M, Saurer M, Reynolds CE, Helle G, Schleser GH, Boettger T, Haupt M, Kno K, Weise SM, Waterhouse JS, Rinne KT, Loader NJ, Sonninen E, Jungner H, Masson-delmotte V, Stievenard M, Pierre M, Pazdur A, Leuenberger M, Filot M, Saurer M, Reynolds CE, Helle G, Schleser GH. 2007. Wood Cellulose Preparation Methods and Mass Spectrometric Analyses of $\delta 13 \mathrm{C}, \delta 18 \mathrm{O}$, and Nonexchangeable $\delta 2 \mathrm{H}$ Values in Cellulose, Sugar, and Starch: An Interlaboratory Comparison. Analytical Chemistry, 79(12): 4603-4612. https://doi.org/10.1021/ac0700023.

Brânduș C, Cristea I. 2004. Anthropic impact in the Călimani’s caldera. Analele Universității de Vest din Timişoara, Geografie, XIV: 159-168.

Briffa KR, Osborn TJ, Schweingrubber F-H. 2004. Large-scale temperature inferences from tree rings: a review. Global and Planetary Change, 40: 11-26.

Brugnoli E, Solomina O, Spaccino L, Dolgova E. 2010. Climate signal in the ring width, density and carbon stable isotopes in pine (Pinus Silvestris L.) in central Caucasus. GEOGRAPHY, ENVIRONMENT, SUSTAINABILITY, 3(4): 4-16. https://doi.org/https://doi.org/10.24057/2071-9388-2010-3-4-4-16.

Bunn AG. 2008. A dendrochronology program library in R (dplR). Dendrochronologia, 26(2): 115-124. https://doi.org/http://dx.doi.org/10.1016/j.dendro.2008.01.002.

Buras A. 2017. A comment on the expressed population signal. Dendrochronologia, 44: 130-132. https://doi.org/doi: 10.1016/j.dendro.2017.03.005.

Carrer M, Urbinati C. 2006. Long-term change in the sensitivity of tree-ring growth to climate forcing in Larix decidua. New Phytologist, 170: 861-872. https://doi.org/10.1111/j.1469-8137.2006.01703.x.

Cassou C, Terray L, Phillips AS. 2005. Tropical Atlantic influence on European heat waves. Journal of Climate, 18(15): 2805-2811. https://doi.org/10.1175/JCLI3506.1.

Cernusak LA, English NB. 2015. Beyond tree-ring widths: Stable isotopes sharpen the focus on climate responses of temperate forest trees. Tree Physiology, 35(1): 1-3. https://doi.org/10.1093/treephys/tpu115.

Compo GP, Whitaker JS, Sardeshmukh PD. 2006. Feasibility of a 100-year reanalysis using only surface pressure data. Bulletin of the American Meteorological Society, 87(2): 175-190. 
Preprint of Nagavciuc, V ; Kern, Z ; lonita, M ; Hartl, C ; Konter, O ; Esper, J ; Popa, I (2020) Climate signals in carbon and oxygen isotope ratios of Pinus cembra tree-ring cellulose from the Călimani Mountains,

Romania. INTERNATIONAL JOURNAL OF CLIMATOLOGY 40: 5 2539-2556.

https://doi.org/10.1175/BAMS-87-2-175.

Compo GP, Whitaker JS, Sardeshmukh PD, Matsui N, Allan RJ, Yin X, Gleason BE, Vose RS, Rutledge G, Bessemoulin P, BroNnimann S, Brunet M, Crouthamel RI, Grant AN, Groisman PY, Jones PD, Kruk MC, Kruger AC, Marshall GJ, Maugeri M, Mok HY, Nordli O, Ross TF, Trigo RM, Wang XL, Woodruff SD, Worley SJ. 2011. The Twentieth Century Reanalysis Project. Quarterly Journal of the Royal Meteorological Society, 137(654): 1-28. https://doi.org/10.1002/qj.776.

Cook E-R, Peters K. 1981. The smoothing spline: a new approuch to standardizing forest interior tree-ring width series for dendroclimatic studies. Tree-ring bulletin, 41: 45-55.

Cook E., Briffa K, Jones PD. 1994. Spatial regression methods in dendroclimatology: a review and comparison of two techniques. International Journal of Climatology. https://doi.org/10.1002/joc.3370140404.

Cook ER. 1985. A time series analysis approach to treering standard-ization. Univ. of Arizona, Tucson, AZ, USA.

Coplen TB. 1994. Reporting of stable hydrogen, carbon, and oxygen isotopic abundances. Pure and Applied Chemistry, 66: 273-276. https://doi.org/10.1351/pac199466020273.

Danis PA, Masson-Delmotte V, Stievenard M, Guillemin MT, Daux V, Naveau P, von Grafenstein U. 2006. Reconstruction of past precipitation $\delta 18 \mathrm{O}$ using tree-ring cellulose $\delta 18 \mathrm{O}$ and $\delta 13 \mathrm{C}$ : A calibration study near Lac d'Annecy, France. Earth and Planetary Science Letters, 243(3-4): 439-448. https://doi.org/10.1016/j.epsl.2006.01.023.

Dansgaard W. 1964. Stable isotopes in precipitation. Tellus, 4: 436-468. https://doi.org/10.3402/tellusa.v16i4.8993.

Daux V, Edouard JL, Masson-Delmotte V, Stievenard M, Hoffmann G, Pierre M, Mestre O, Danis PA, Guibal F. 2011. Can climate variations be inferred from tree-ring parameters and stable isotopes from Larix decidua? Juvenile effects, budmoth outbreaks, and divergence issue. Earth and Planetary Science Letters. Elsevier B.V., 309(3-4): 221-233. https://doi.org/10.1016/j.eps1.2011.07.003.

Della-Marta PM, Haylock MR, Luterbacher J, Wanner H. 2007. Doubled length of western European summer heat waves since 1880. Journal of Geophysical Research Atmospheres, 112(15): 1-11. https://doi.org/10.1029/2007JD008510.

Duffy JE, McCarroll D, Barnes A, Bronk Ramsey C, Davies D, Loader NJ, Miles D, Young GHF. 2017. Short-lived juvenile effects observed in stable carbon and oxygen isotopes of UK oak trees and historic building timbers. Chemical Geology, 472: 1-7. https://doi.org/10.1016/j.chemgeo.2017.09.007.

Dumitrescu A, Birsan M. 2015. ROCADA: a gridded daily climatic dataset over Romania (1961 - 2013) for nine meteorological variables. Natural Hazards. Springer Netherlands, 78: 1045-1063. https://doi.org/10.1007/s11069-015-1757-z.

Esper J, Frank D, Büntgen U, Verstege A, Hantemirov R, Kirdyanov A V. 2010. Trends and uncertainties in Siberian indicators of 20th century warming. Global Change Biology, 16(1): 386-398. https://doi.org/10.1111/j.1365-2486.2009.01913.x.

Esper J, Holzkämper S, Büntgen U, Schöne B, Keppler F, Hartl C, George SS, Riechelmann DFC, Treydte K. 2018. Site-specific climatic signals in stable isotope records from Swedish pine forests. Trees Structure and Function. Springer Berlin Heidelberg, 32(3): 855-869. https://doi.org/10.1007/s00468-018-1678-z. 
Preprint of Nagavciuc, V ; Kern, Z ; lonita, M ; Hartl, C ; Konter, O ; Esper, J ; Popa, I (2020) Climate signals in carbon and oxygen isotope ratios of Pinus cembra tree-ring cellulose from the Călimani Mountains,

Romania. INTERNATIONAL JOURNAL OF CLIMATOLOGY 40: 5 2539-2556.

546

547

548

549

550

551

552

553

554

555

556

557

558

559

560

561

562

563

564

565

566

567

568

569

570

571

572

573

574

575

576

577

578

579

580

581

582

583

584

585

586

587

Esper J, Konter O, Krusic PJ, Saurer M, Holzkämper S, Büntgen U. 2015. Long-term summer temperature variations in the Pyrenees from detrended stable carbon isotopes. Geochronometria, 42(1): 53-59. https://doi.org/10.1515/geochr-2015-0006.

Farquhar GD, Ehleringer JR, Hubick KT. 1989. Carbon Isotope Discrimination and Photosynthesis. Annual Review of Plant Physiology and Plant Molecular Biology, 40(1): 503-537. https://doi.org/10.1146/annurev.pp.40.060189.002443.

Feudale L, Shukla J. 2011. Influence of sea surface temperature on the European heat wave of 2003 summer. Part II: a modeling study. Climate Dynamics, 36(9-10): 1705-1715. https://doi.org/10.1007/s00382-010-0789-z.

Gagen M, Mccarroll D, Edouard J. 2004. Latewood Width, Maximum Density, and Stable Carbon Isotope Ratios of Pine as Climate Indicators in a Dry Subalpine Environment, French Alps. Arctic, Antarctic, and Alpine Research, 36(2): 166-171. https://doi.org/10.1657/15230430(2004)036[0166:LWMDAS]2.0.CO;2.

Gagen M, McCarroll D, Robertson I, Loader NJ, Jalkanen R. 2008. Do tree ring $813 \mathrm{C}$ series from Pinus sylvestris in northern Fennoscandia contain long-term non-climatic trends? Chemical Geology, 252(1-2): 42-51. https://doi.org/http://dx.doi.org/10.1016/j.chemgeo.2008.01.013.

Gagen M, Zorita E, McCarroll D, Young GHF, Grudd H, Jalkanen R, Loader NJ, Robertson I, Kirchhefer A. 2011. Cloud response to summer temperatures in Fennoscandia over the last thousand years. Geophysical Research Letters, 38(5): 1-5. https://doi.org/10.1029/2010GL046216.

Gessler A, Ferrio JP, Hommel R, Treydte K, Werner RA, Monson RK. 2014. Stable isotopes in tree rings: Towards a mechanistic understanding of isotope fractionation and mixing processes from the leaves to the wood. Tree Physiology, 34(8): 796-818. https://doi.org/10.1093/treephys/tpu040.

Grissino-Mayer HD. 1997. Computer assisted independent observer verification tree ring measurements. Tree Ring Bulletin, 54: 29-41.

Grissino-Mayer HD. 2001. Evaluating crossdating accurasy: a manual and tutorial for the computer program Cofecha. Tree-Ring Research, 57(2): 205-221.

Hafner P, McCarroll D, Robertson I, Loader NJ, Gagen M, Young GHF, Bale RJ, Sonninen E, Levanič T. 2014. A 520 year record of summer sunshine for the eastern European Alps based on stable carbon isotopes in larch tree rings. Climate Dynamics, 43(3): 971-980. https://doi.org/10.1007/s00382-0131864-z.

Harris I, Jones PD, Osborn TJ, Lister DH. 2014. Updated high-resolution grids of monthly climatic observations - the CRU TS3.10 Dataset. International Journal of Climatology, 34(3): 623-642. https://doi.org/10.1002/joc.3711.

Hartl-Meier C, Zang C, Büntgen U, Esper J, Rothe A, Göttlein A, Dirnböck T, Treydte K. 2015. Uniform climate sensitivity in tree-ring stable isotopes across species and sites in a mid-latitude temperate forest. Tree Physiology, 35(1): 4-15. https://doi.org/10.1093/treephys/tpu096.

Haupt M, Weigl M, Grabner M, Boettger T. 2011. A 400-year reconstruction of July relative air humidity for the Vienna region (eastern Austria) based on carbon and oxygen stable isotope ratios in tree-ring latewood cellulose of oaks (Quercus petraea Matt. Liebl.). Climatic Change, 105(1): 243-262. https://doi.org/10.1007/s10584-010-9862-1.

Holmes RL. 1983. Computer-assisted quality control in tree-ring dating and measurement. Tree Ring Bulletin, 43: 69-75. 
Preprint of Nagavciuc, V ; Kern, Z ; lonita, M ; Hartl, C ; Konter, O ; Esper, J ; Popa, I (2020) Climate signals in carbon and oxygen isotope ratios of Pinus cembra tree-ring cellulose from the Călimani Mountains,

Romania. INTERNATIONAL JOURNAL OF CLIMATOLOGY 40: 5 2539-2556.

588

589

590

591

592

593

594

595

596

597

598

599

600

601

602

603

604

605

606

607

608

609

610

611

612

613

614

615

616

617

618

619

620

621

622

623

624

625

626

627

628

629

Hughes MK, Swetnam TW, Diaz HF (eds). 2011. Dendroclimatology Progress and Prospects. Springer Science \& Business Media.

Ionita M. 2015. Interannual summer streamflow variability over Romania and its connection to large-scale atmospheric circulation. International Journal of Climatology, 35(14): 4186-4196. https://doi.org/10.1002/joc.4278.

Ionita M. 2017. Mid range forecasting of the German Waterways streamflow based on hydrologic, atmospheric and oceanic data. Alfred Wegener Institute for Polar and Marine Research. Bremerhaven, 711.

Ionita M, Dima M, Lohmann G, Scholz P, Rimbu N. 2014. Predicting the June 2013 European Flooding Based on Precipitation, Soil Moisture, and Sea Level Pressure. Journal of Hydrometeorology, 16(2): 598-614. https://doi.org/10.1175/JHM-D-14-0156.1.

Ionita M, Lohmann G, Rimbu N. 2008. Prediction of spring Elbe discharge Based on stable teleconnections with winter global temperature and precipitation. Journal of Climate, 21(23): 6215-6226. https://doi.org/10.1175/2008JCLI2248.1.

Ionita M, Lohmann G, Rimbu N, Chelcea S, Dima M. 2012. Interannual to decadal summer drought variability over Europe and its relationship to global sea surface temperature. Climate Dynamics, 38: 363-377. https://doi.org/10.1007/s00382-011-1028-y.

Ionita M, Scholz P, Grosfeld K, Treffeisen R. 2018. Moisture transport and Antarctic sea ice: Austral spring 2016 event. Earth System Dynamics Discussions, 9(December): 939-954. https://doi.org/10.5194/esd-2017-114.

Ionita M, Tallaksen LM, Kingston D, Stagge JH, Laaha G, Van Lanen HAJ, Scholz P, Chelcea SM, Haslinger K. 2017. The European 2015 drought from a climatological perspective. Hydrology and Earth System Sciences, 21: 1397-1419. https://doi.org/doi:10.5194/hess-21-1397-2017.

IPCC. 2014. IPPC Climate Change 2014 Synthesis Report. Climate Change 2014: Synthesis Report. Contribution of Working Groups I, II and III to the Fifth Assessment Report of the Intergovernmental Panel on Climate Change. Geneva, Switzerland.

Jacoby GC, Lovelius N V., Shumilov OI, Raspopov OM, Karbainov JM, Frank DC. 2000. Long-term temperature trends and tree growth in the Taymir region of northern Siberia. Quaternary Research, 53(3): 312-318. https://doi.org/10.1006/qres.2000.2130.

Keeling CD. 1979. The Suess effect:13Carbon-14Carbon interrelations. Environment International, 2(46): 229-300. https://doi.org/10.1016/0160-4120(79)90005-9.

Kern Z, Popa I. 2008. Changes of Frost Damage and Treeline Advance for Swiss Stone Pine in the Calimani Mts. (Eastern Carpathians, Romania). Acta Silvatica et Lignaria Hungarica, 4: 39-48.

Kern Z, Popa I, Varga Z, Széles É. 2009. Degraded temperature sensitivity of a stone pine chronology explained by dendrochemical evidences. Dendrochronologia, 27(2): 121-128. https://doi.org/http://dx.doi.org/10.1016/j.dendro.2009.06.005.

Kilroy E, McCarroll D, Young GH, Loader NJ, Bale RJ. 2016. Absence of juvenile effects confirmed in stable carbon and oxygen isotopes of European larch trees. Acta Silvae et Ligni, 111(111): 27-33. https://doi.org/10.20315/ASetL.111.3.

Kimak A, Leuenberger M. 2015. Are carbohydrate storage strategies of trees traceable by early-latewood carbon isotope differences? Trees - Structure and Function, 29(3): 859-870. https://doi.org/10.1007/s00468-015-1167-6. 
Preprint of Nagavciuc, V ; Kern, Z ; lonita, M ; Hartl, C ; Konter, O ; Esper, J ; Popa, I (2020) Climate signals in carbon and oxygen isotope ratios of Pinus cembra tree-ring cellulose from the Călimani Mountains,

Romania. INTERNATIONAL JOURNAL OF CLIMATOLOGY 40: 5 2539-2556.

630

631

632

633

634

635

636

637

638

639

640

641

642

643

644

645

646

647

648

649

650

651

652

653

654

655

656

657

658

659

660

661

662

663

664

665

666

667

668

669

670

671

Kingston DG, Fleig AK, Tallaksen LM, Hannah DM. 2013. Ocean-Atmosphere Forcing of Summer Streamflow Drought in Great Britain. Journal of Hydrometeorology, 14(1): 331-344. https://doi.org/10.1175/JHM-D-11-0100.1.

Kingston DG, Stagge JH, Tallaksen LM, Hannah DM. 2015. European-scale drought: Understanding connections between atmospheric circulation and meteorological drought indices. Journal of Climate, 28(2): 505-516. https://doi.org/10.1175/JCLI-D-14-00001.1.

Konter O, Holzkämper S, Helle G, Büntgen U, Saurer M, Esper J. 2014. Climate sensitivity and parameter coherency in annually resolved $\delta 13 \mathrm{C}$ and $\delta 18 \mathrm{O}$ from Pinus uncinata tree-ring data in the Spanish Pyrenees. Chemical Geology. Elsevier B.V., $\quad 377$ : 12-19. https://doi.org/10.1016/j.chemgeo.2014.03.021.

Kress A, Saurer M, Siegwolf RTW, Frank DC, Esper J, Bugmann H. 2010. A 350 year drought reconstruction from Alpine tree ring stable isotopes. Global Biogeochemical Cycles, 24: 1-16. https://doi.org/10.1029/2009GB003613.

Labuhn I, Daux V, Girardclos O, Stievenard M, Pierre M, Masson-Delmotte V. 2016. French summer droughts since $1326 \mathrm{CE}$ : A reconstruction based on tree ring cellulose $\delta 18 \mathrm{O}$. Clim. Past, 12: 11011117. https://doi.org/doi:10.5194/cp-12-1101-2016.

Laumer W, Andreu L, Helle G, Schleser GH, Wieloch T, Wissel H. 2009. A novel approach for the homogenization of cellulose to use micro-amounts for stable isotope analyses. Rapid Communications in Mass Spectrometry, 23(13): 1934-1940.

Leavitt SW. 2010. Tree-ring C-H-O isotope variability and sampling. Science of The Total Environment, 408(22): 5244-5253. https://doi.org/http://dx.doi.org/10.1016/j.scitotenv.2010.07.057.

Leonelli G, Pelfini M, Battipaglia G, Cherubini P. 2009. Site-aspect influence on climate sensitivity over time of a high-altitude Pinus cembra tree-ring network. Climatic Change, 96(1): 185-201. https://doi.org/10.1007/s10584-009-9574-6.

Leuenberger M. 2007. Stable Isotopes as Indicators of Ecological Change. Terrestrial Ecology.

Leuenberger MC, Filot MS. 2007. Temperature dependencies of high-temperature reduction on conversion products and their isotopic signatures. Rapid Commun. Mass Spectrom, 21: 1587-1598. https://doi.org/10.1002/rcm.

Loader ANJ, Waterhouse JS. 2014. An Extractor Device for Stuck or Broken Increment Borers. Tree Ring Bulletin, 70(2): 157-160. https://doi.org/10.3959/1536-1098-70.2.157.

Loader NJ, Robertson I, Barker a. C, Switsur VR, Waterhouse JS. 1997. An improved technique for the batch processing of small wholewood samples to $\alpha$-cellulose. Chemical Geology, 136(3-4): 313317. https://doi.org/10.1016/S0009-2541(96)00133-7.

Loader NJ, Santillo PM, Woodman-Ralph JP, Rolfe JE, Hall MA, Gagen M, Robertson I, Wilson R, Froyd CA, McCarroll D. 2008. Multiple stable isotopes from oak trees in southwestern Scotland and the potential for stable isotope dendroclimatology in maritime climatic regions. Chemical Geology, 252(1-2): 62-71. https://doi.org/http://dx.doi.org/10.1016/j.chemgeo.2008.01.006.

McCarroll D, Loader NJ. 2004. Stable isotopes in tree rings. Quaternary Science Reviews, 23(7-8): 771801. https://doi.org/http://dx.doi.org/10.1016/j.quascirev.2003.06.017.

Mutihac V. 2004. Geologia României. Editura Didactică şi Pedagogică: Bucuresti.

Nagavciuc V, Ionita M, Perşoiu A, Popa I, Loader NJ, McCarroll D. 2019. Stable oxygen isotopes in Romanian oak tree rings record summer droughts and associated large-scale circulation patterns over 
Preprint of Nagavciuc, V ; Kern, Z ; Ionita, M ; Hartl, C ; Konter, O ; Esper, J ; Popa, I (2020) Climate signals in carbon and oxygen isotope ratios of Pinus cembra tree-ring cellulose from the Călimani Mountains,

Romania. INTERNATIONAL JOURNAL OF CLIMATOLOGY 40: 5 2539-2556.

Europe. Climate Dynamics, 52: 6557-6568. https://doi.org/doi.org/10.1007/s00382-018-4530-7.

Nagavciuc V, Kern Z, Perşoiu A, Kesjár D, Popa I. 2018. Aerial decay influence on the stable oxygen and carbon isotope ratios in tree ring cellulose. Dendrochronologia. Urban \& Fischer, 49: 110-117. https://doi.org/10.1016/J.DENDRO.2018.03.007.

NOAA. 2019. The International Tree-Ring Data Bank. ITRDB.

Pallardy SG. 2008. Physiology of woody plants. Third Edition. Elsevier Academic Press.

Popa I. 2016. Multi-secular trees between myth and reality. Revista de Silvicultură și Cinegetică, 21(38): 31-34.

Popa I, Kern Z. 2009. Long-term summer temperature reconstruction inferred from tree ring records from the Eastern Carpathians. Climate Dynamics, 32: 1107-1117.

R Development Core Team. 2014. R: A language and environment for statistical computing. R Foundation for Statistical Computing, Vienna, Austria.

Rayner NA, Parker DE, Horton EB, Folland CK, Alexander LV, Rowell DP. 2003. Global analyses of sea surface temperature, sea ice, and night marine air temperature since the late nineteenth century. Journal of Geophysical Research, 108(D14): 4407. https://doi.org/10.1029/2002JD002670.

Rinne KT, Loader NJ, Switsur VR, Waterhouse JS. 2013. 400-year May - August precipitation reconstruction for Southern England using oxygen isotopes in tree rings. Quaternary Science Reviews. Elsevier Ltd, 60: 13-25. https://doi.org/10.1016/j.quascirev.2012.10.048.

Roden J, Lin G, Ehleringer JR. 2000. A mechanistic model for interpretation of hydrogen and oxygen isotope ratios in tree-ring cellulose. Geochimica et Cosmochimica Acta, 64(1): 21-35.

Saurer M, Cherubini P, Reynolds-Henne CE, Treydte KS, Anderson WT, Siegwolf RTW. 2008. An investigation of the common signal in tree ring stable isotope chronologies at temperate sites. Journal of Geophysical Research: Biogeosciences. https://doi.org/10.1029/2008JG000689.

Schubert BA, Jahren AH. 2012. The effect of atmospheric CO2 concentration on carbon isotope fractionation in C3 land plants. Geochimica et Cosmochimica Acta. Elsevier Ltd, 96: 29-43. https://doi.org/10.1016/j.gca.2012.08.003.

Schubert SD, Wang H, Koster RD, Suarez MJ, Groisman PY. 2014. Northern Eurasian heat waves and droughts. Journal of Climate, 27(9): 3169-3207. https://doi.org/10.1175/JCLI-D-13-00360.1.

Spinoni J, Lakatos M, Szentimrey T, Bihari Z, Szalai S, Vogt J, Antofie T. 2015. Heat and cold waves trends in the Carpathian Region from 1961 to 2010. International Journal of Climatology, 35(14): 4197-4209. https://doi.org/10.1002/joc.4279.

Treydte K, Frank D, Esper J, Andreu L, Bednarz Z, Berninger F, Boettger T, D’Alessandro CM, Etien N, Filot M, Grabner M, Guillemin MT, Gutierrez E, Haupt M, Helle G, Hilasvuori E, Jungner H, KalelaBrundin M, Krapiec M, Leuenberger M, Loader NJ, Masson-Delmotte V, Pazdur A, Pawelczyk S, Pierre M, Planells O, Pukiene R, Reynolds-Henne CE, Rinne KT, Saracino A, Saurer M, Sonninen E, Stievenard M, Switsur VR, Szczepanek M, Szychowska-Krapiec E, Todaro L, Waterhouse JS, Weigl M, Schleser GH. 2007. Signal strength and climate calibration of a European tree-ring isotope network. Geophysical Research Letters, 34, L24302(24): 1-6. https://doi.org/10.1029/2007GL031106.

Treydte KS, Frank DC, Saurer M, Helle G, Schleser GH, Esper J. 2009. Impact of climate and CO2on a millennium-long tree-ring carbon isotope record. Geochimica et Cosmochimica Acta. Elsevier Ltd, 73(16): 4635-4647. https://doi.org/10.1016/j.gca.2009.05.057. 
Preprint of Nagavciuc, V ; Kern, Z ; lonita, M ; Hartl, C ; Konter, O ; Esper, J ; Popa, I (2020) Climate signals in carbon and oxygen isotope ratios of Pinus cembra tree-ring cellulose from the Călimani Mountains,

Romania. INTERNATIONAL JOURNAL OF CLIMATOLOGY 40: 5 2539-2556.

714

715

716

717

718

719

720

721

722

723

724

725

726

727

728

729

730

731

732

733

734

735

736

737

738

739

740

741

742

743

Van Lanen HAJ, Laaha G, Kingston DG, Gauster T, Ionita M, Vidal JP, Vlnas R, Tallaksen LM, Stahl K, Hannaford J, Delus C, Fendekova M, Mediero L, Prudhomme C, Rets E, Romanowicz RJ, Gailliez S, Wong WK, Adler MJ, Blauhut V, Caillouet L, Chelcea S, Frolova N, Gudmundsson L, Hanel M, Haslinger K, Kireeva M, Osuch M, Sauquet E, Stagge JH, Van Loon AF. 2016. Hydrology needed to manage droughts: the 2015 European case. Hydrological Processes, 30(17): 3097-3104. https://doi.org/10.1002/hyp.10838.

Whitaker JS, Compo GP, Wei X, Hamill TM. 2004. Reanalysis before radiosondes using ensemble data assimilation. Bulletin of the American Meteorological Society, 132: 2983-2991. https://doi.org/10.1175/1520-0493(2004)132<1190:RWRUED>2.0.CO;2.

Wigley TML, Briffa KR, Jones PD. 1984. On the Average Value of Correlated Time Series, with Applications in Dendroclimatology and Hydrometeorology. Journal of Climate and Applied Meteorology, 23(2): 201-213. https://doi.org/doi:10.1175/15200450(1984)023<0201:OTAVOC>2.0.CO;2.

Xu C, Shao X, An W, Nakatsuka T, Zhang Y, Sano M, Guo Z. 2017. Negligible local-factor influences on tree ring cellulose $\delta^{18} \mathrm{O}$ of Qilian juniper in the Animaqing Mountains of the eastern Tibetan Plateau. Tellus B: Chemical and Physical Meteorology. Taylor \& Francis, 69(1): 1391663. https://doi.org/10.1080/16000889.2017.1391663.

Xu G, Liu X, Qin D, Chen T, Wang W, Wu G, Sun W, An W, Zeng X. 2014. Tree-ring $\delta 18$ O evidence for the drought history of eastern Tianshan Mountains, northwest China since 1700 AD. International Journal of Climatology, 34(12): 3336-3347. https://doi.org/10.1002/joc.3911.

Young GHF, Loader NJ, McCarroll D, Bale RJ, Demmler JC, Miles D, Nayling NT, Rinne KT, Robertson I, Watts C, Whitney M. 2015. Oxygen stable isotope ratios from British oak tree-rings provide a strong and consistent record of past changes in summer rainfall. Climate Dynamics, 45(11): 36093622. https://doi.org/10.1007/s00382-015-2559-4.

Young GHF, McCarroll D, Loader NJ, Kirchhefer AJ. 2010. A 500-year record of summer near-ground solar radiation from tree-ring stable carbon isotopes. Holocene, 20(3): 315-324. https://doi.org/10.1177/0959683609351902.

Zang C, Biondi F. 2015. Treeclim: An R package for the numerical calibration of proxy-climate relationships. Ecography, 38(4): 431-436. https://doi.org/10.1111/ecog.01335. 

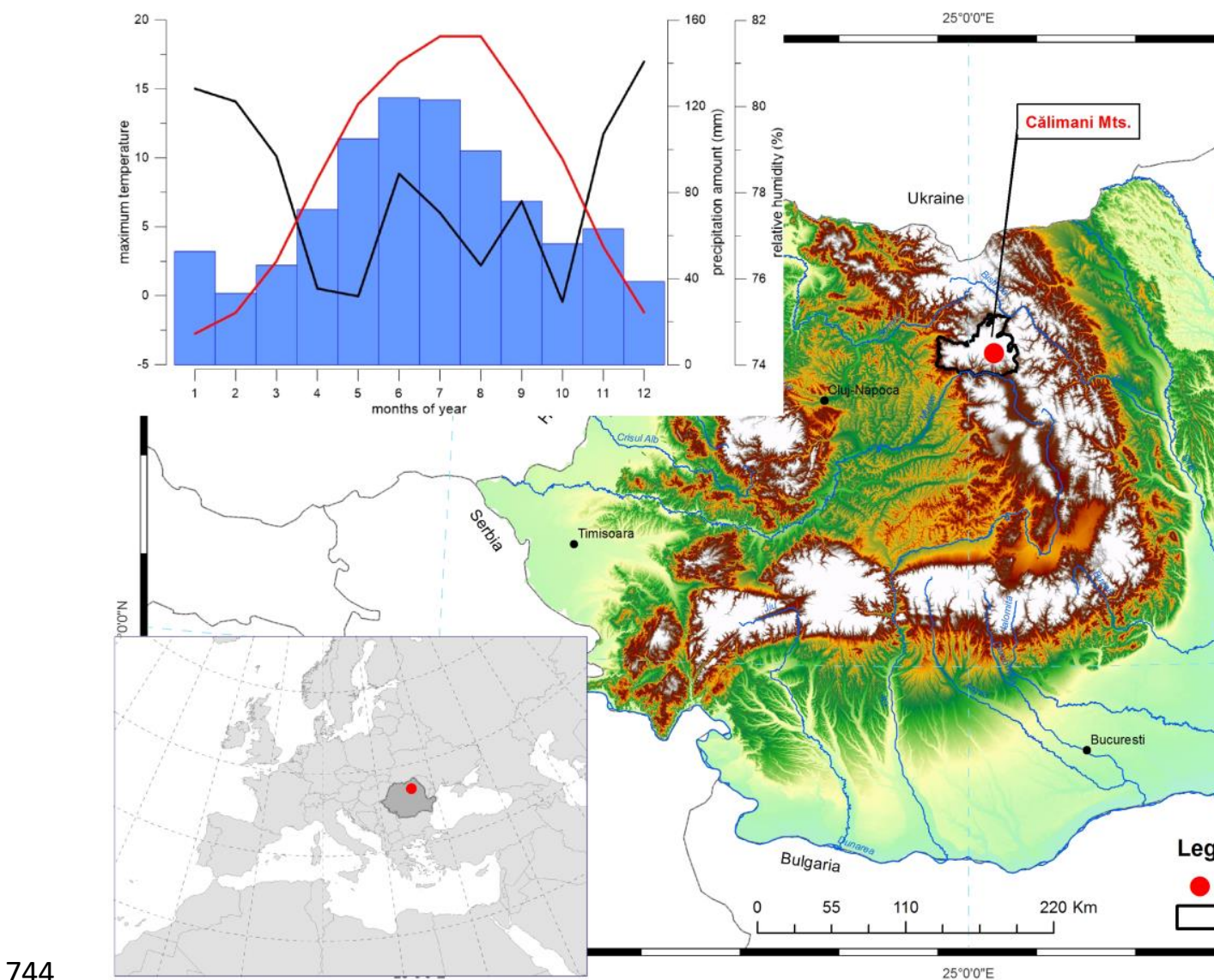

Figure 1. Location of the investigation area in Europe (inset bottom left) and a topographic map of Romania showing the sampling site. Insert in the top left represents the annual variation of the max temperature (red), precipitation (blue) and relative humidity (black) over the 1961-2013 period form the ROCADA gridded data (Dumitrescu and Birsan, 2015) for the nearest grid point of study site. 
Preprint of Nagavciuc, V ; Kern, Z ; Ionita, M ; Hartl, C ; Konter, O ; Esper, J ; Popa, I (2020) Climate signals in carbon and oxygen isotope ratios of Pinus cembra tree-ring cellulose from the Călimani Mountains,

Romania. INTERNATIONAL JOURNAL OF CLIMATOLOGY 40: 5 2539-2556.

(a)

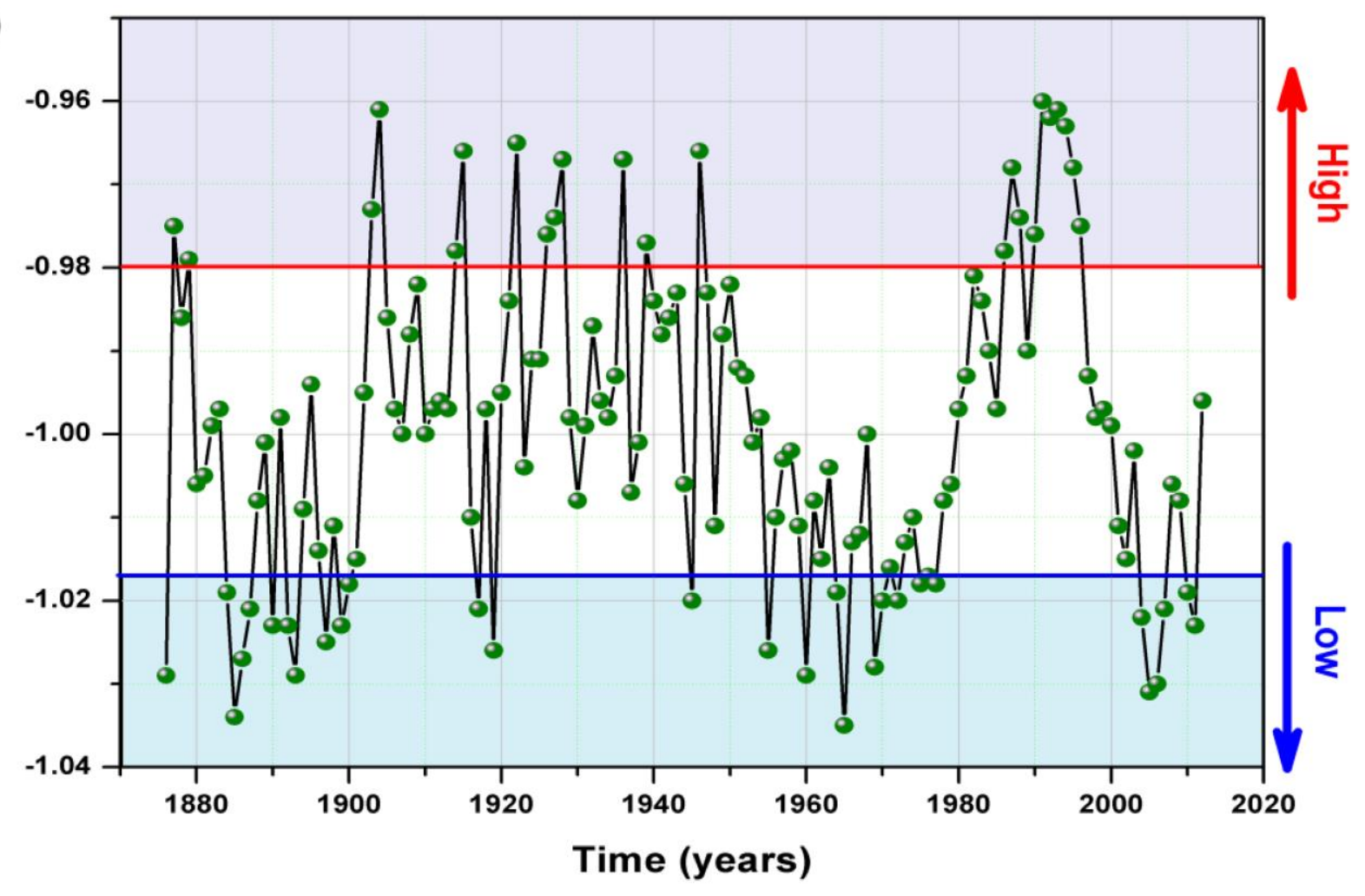

(b)

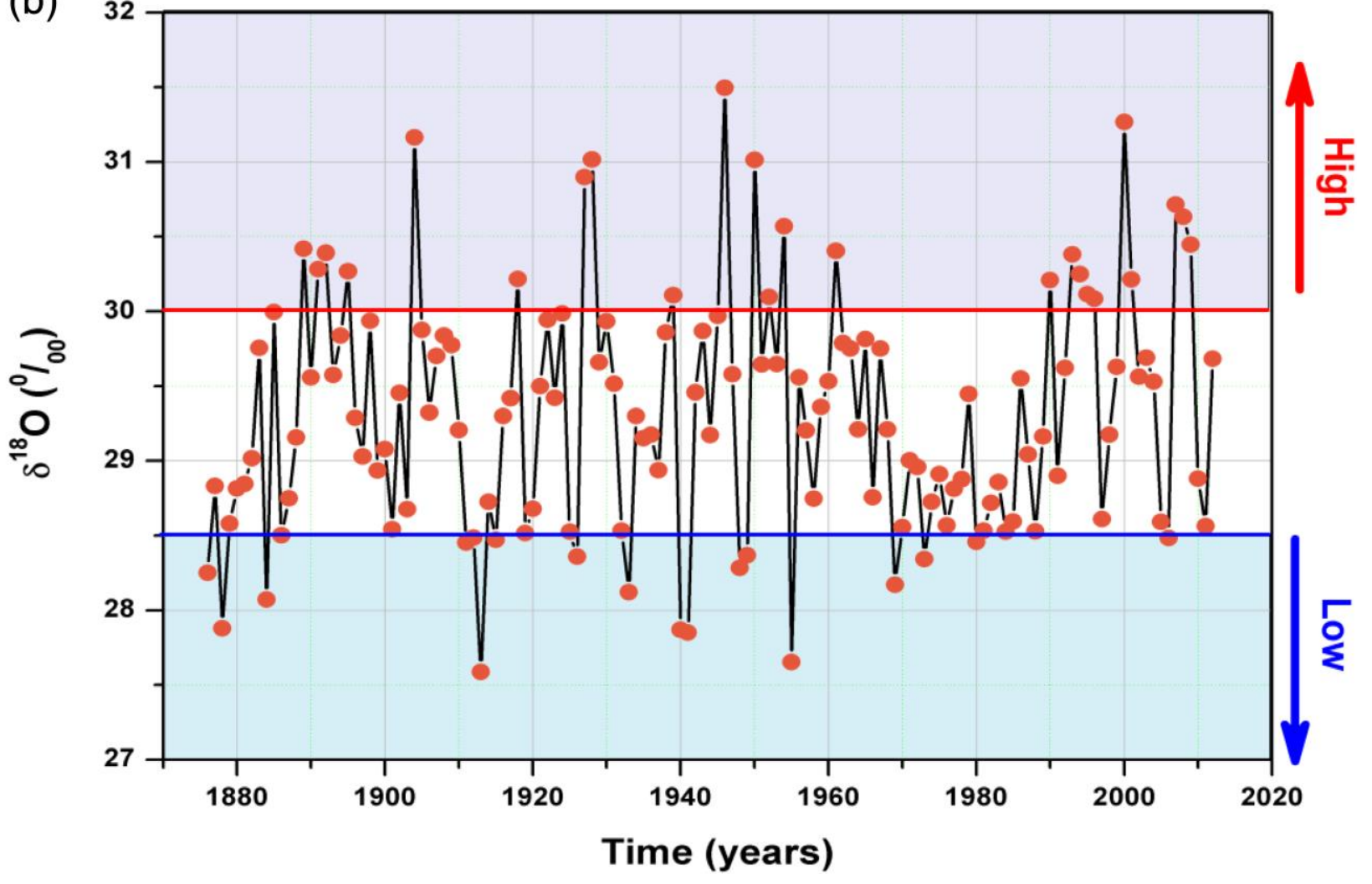


Preprint of Nagavciuc, V ; Kern, Z ; lonita, M ; Hartl, C ; Konter, O ; Esper, J ; Popa, I (2020) Climate signals in carbon and oxygen isotope ratios of Pinus cembra tree-ring cellulose from the Călimani Mountains, Romania. INTERNATIONAL JOURNAL OF CLIMATOLOGY 40: 5 2539-2556.
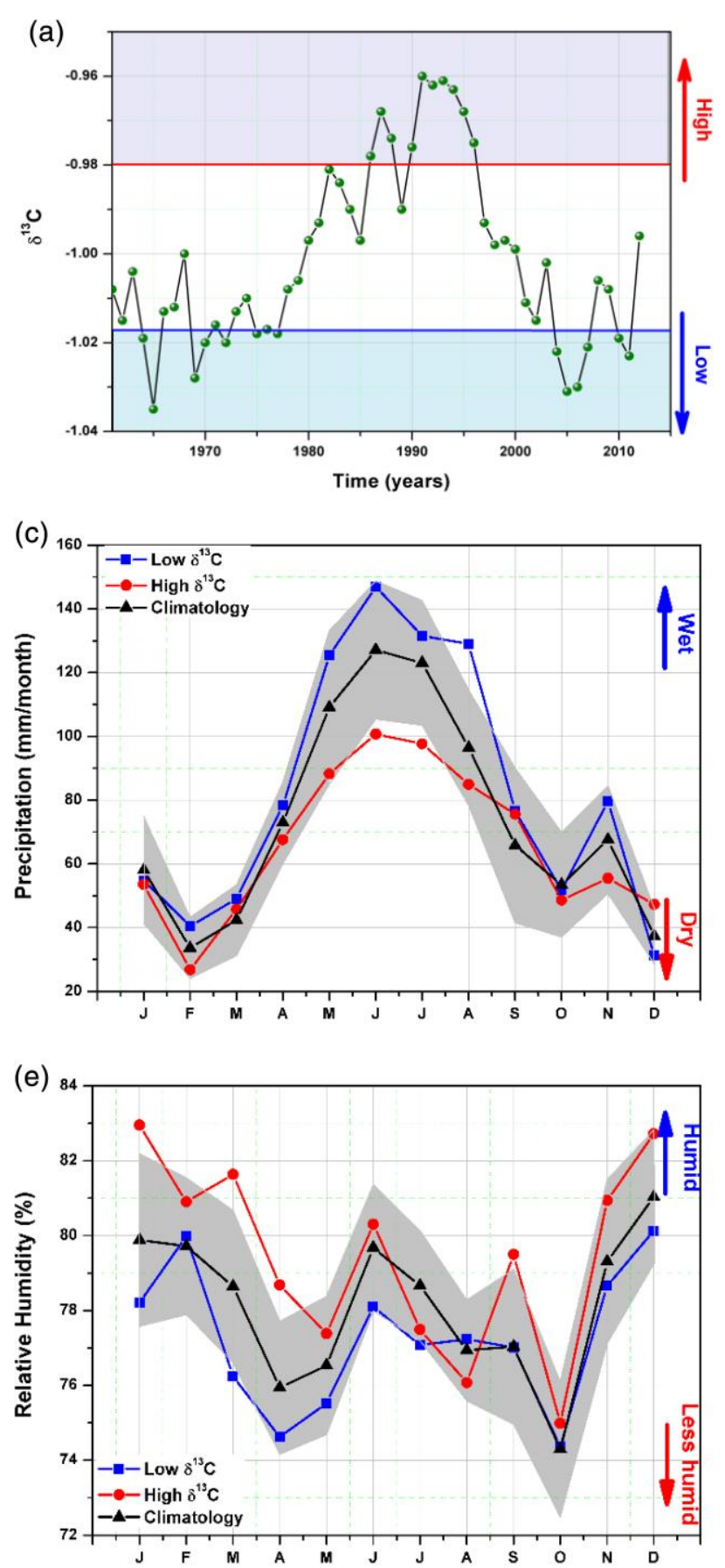
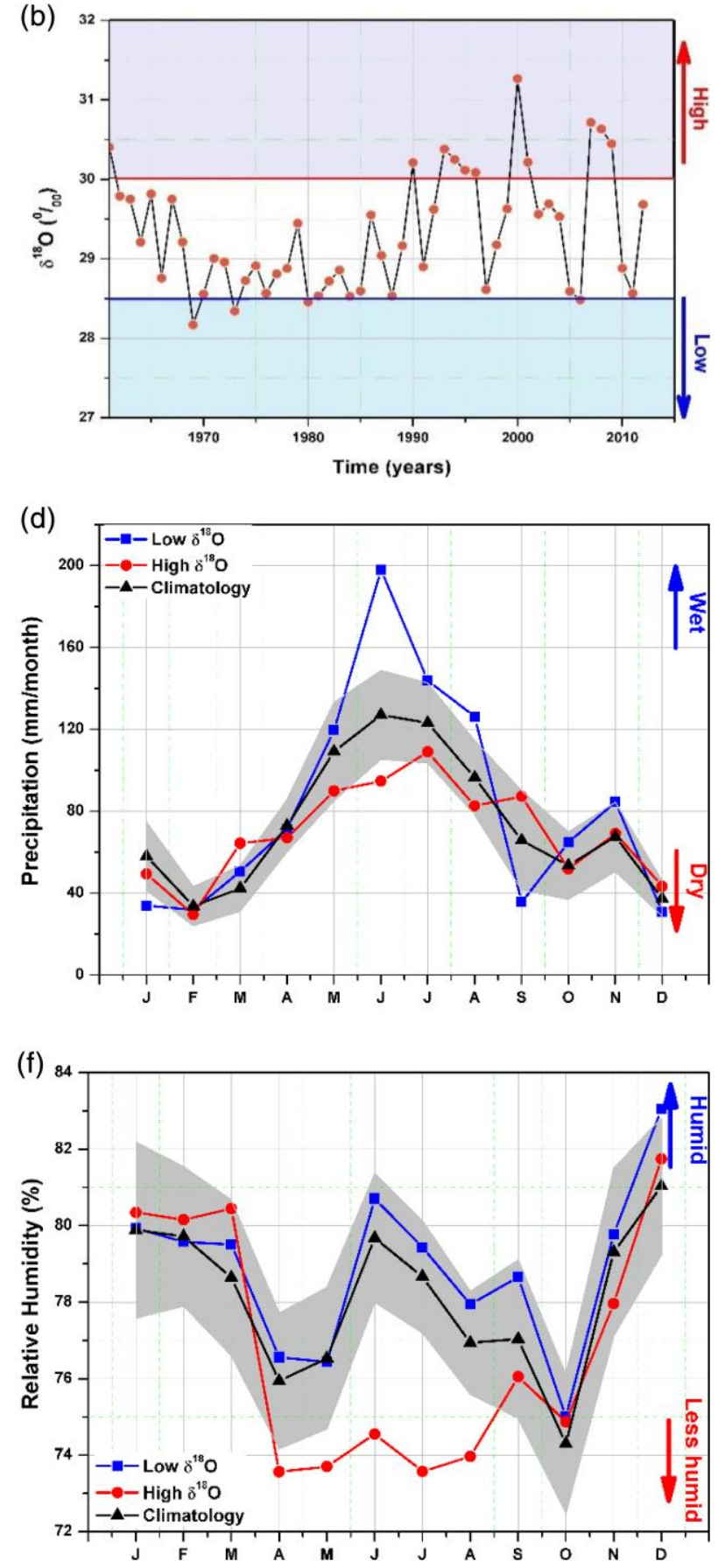

Figure 2. The temporal evolution of the a) detrended $\delta^{13} \mathrm{C}$ and b) $\delta^{18} \mathrm{O}$ chronologies over the period 1876 -2012. The shaded areas indicate the years used for the composite maps in Figures 6 and 7.

Figure 3. The temporal evolution of the a) detrended $\delta^{13} \mathrm{C}$; b) $\delta^{18} \mathrm{O}$ chronologies over the period $1961-$ 2013 ; c) the seasonal cycle for precipitation during years with extreme $\delta^{13} \mathrm{C}$ values (shaded area in a); d) the seasonal cycle for precipitation during years with extreme $\delta^{18} \mathrm{O}$ values (shaded area in b); e) As in c) but for relative humidity and f) as in d) but for relative humidity. In c), d), e) and f) the gray lines indicate 
Preprint of Nagavciuc, V ; Kern, Z ; lonita, M ; Hartl, C ; Konter, O ; Esper, J ; Popa, I (2020) Climate signals in carbon and oxygen isotope ratios of Pinus cembra tree-ring cellulose from the Călimani Mountains, Romania. INTERNATIONAL JOURNAL OF CLIMATOLOGY 40: 5 2539-2556.

758

759

760

761

762

the seasonal cycle over the whole analyzed period $(1961$ - 2013), the red lines indicate the seasonal cycle for low values of $\delta^{13} \mathrm{C}$ and $\delta^{18} \mathrm{O}$ and the blue lines indicate the seasonal cycle for high values of $\delta^{13} \mathrm{C}$ and $\delta^{18} \mathrm{O}$. Where the coloured lines lie outside the grey shading, deviations higher/smaller than 1 standard deviation from average conditions occur.

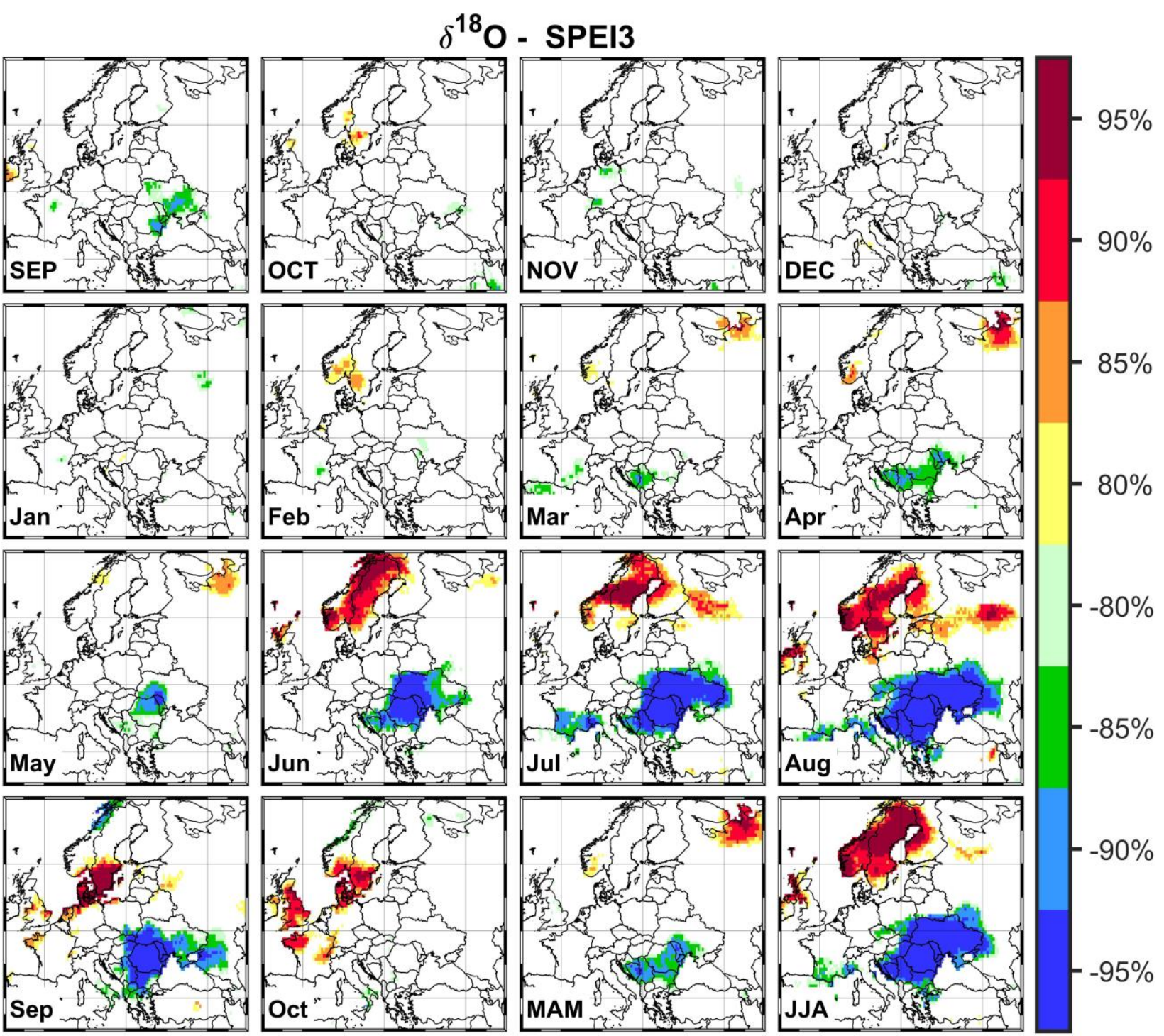

Figure 4. Stability map of the correlation between $\delta^{18} \mathrm{O}$ and SPEI3 from previous year September until current year October. Regions where the correlation is stable, positive and significant for at least $80 \%$ windows are shaded with dark red (95\%), red (90\%), orange (85\%) and yellow (80\%). The corresponding regions where the correlation is stable, but negative, are shaded with dark blue $(95 \%)$, blue $(90 \%)$, green $(85 \%)$ and light green $(80 \%)$. SEP - September previous year, OCT - October previous year, NOV November previous year, DEC - December previous year, Jan - January, Feb - February, Mar - March, Apr - April, May - May, Jun - June, Jul - July, Aug - August, Sep - September, Oct - October, MAM march/April/May and JJA - June/July/August. Analyzed period: 1902 - 2012. 

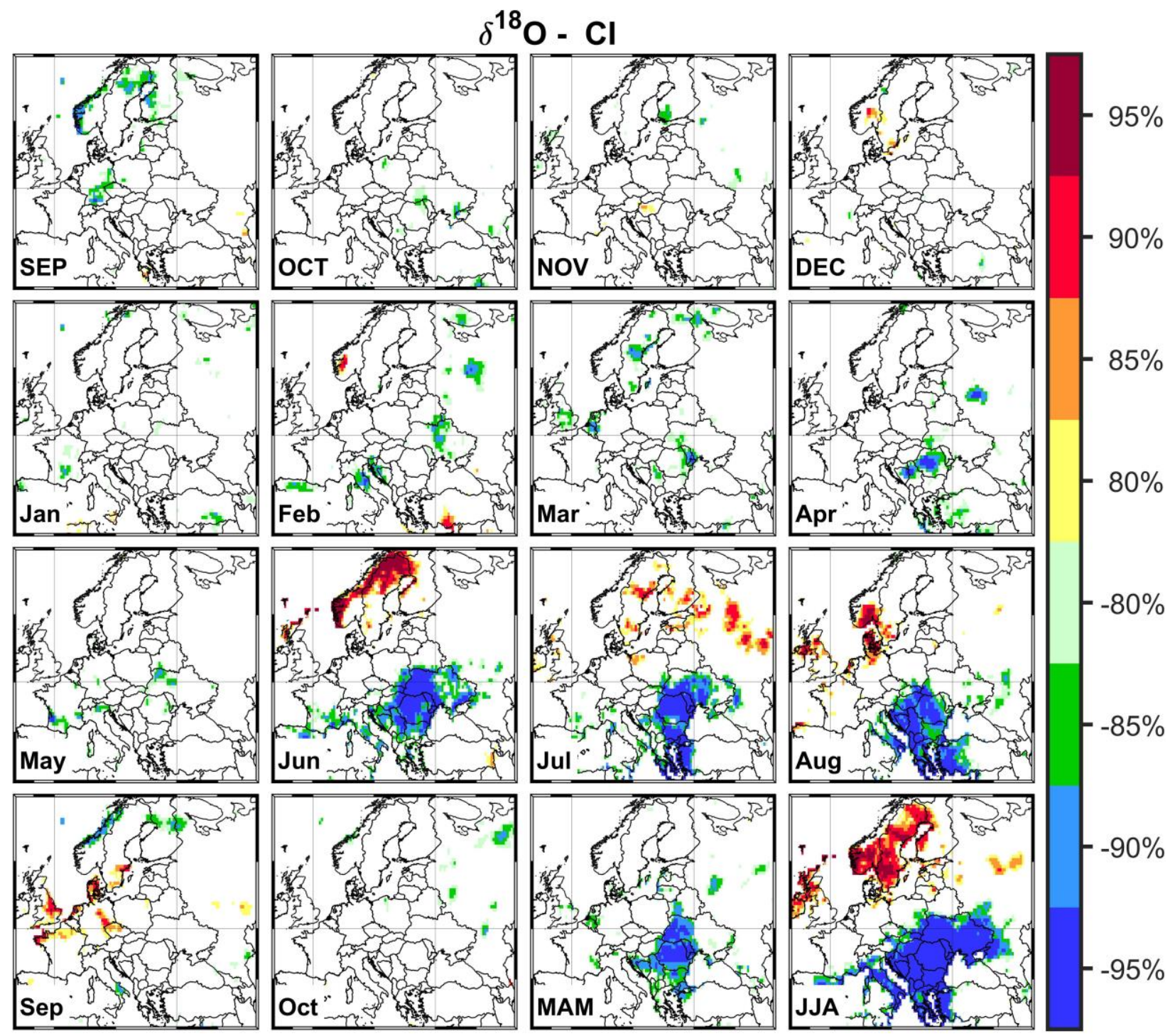
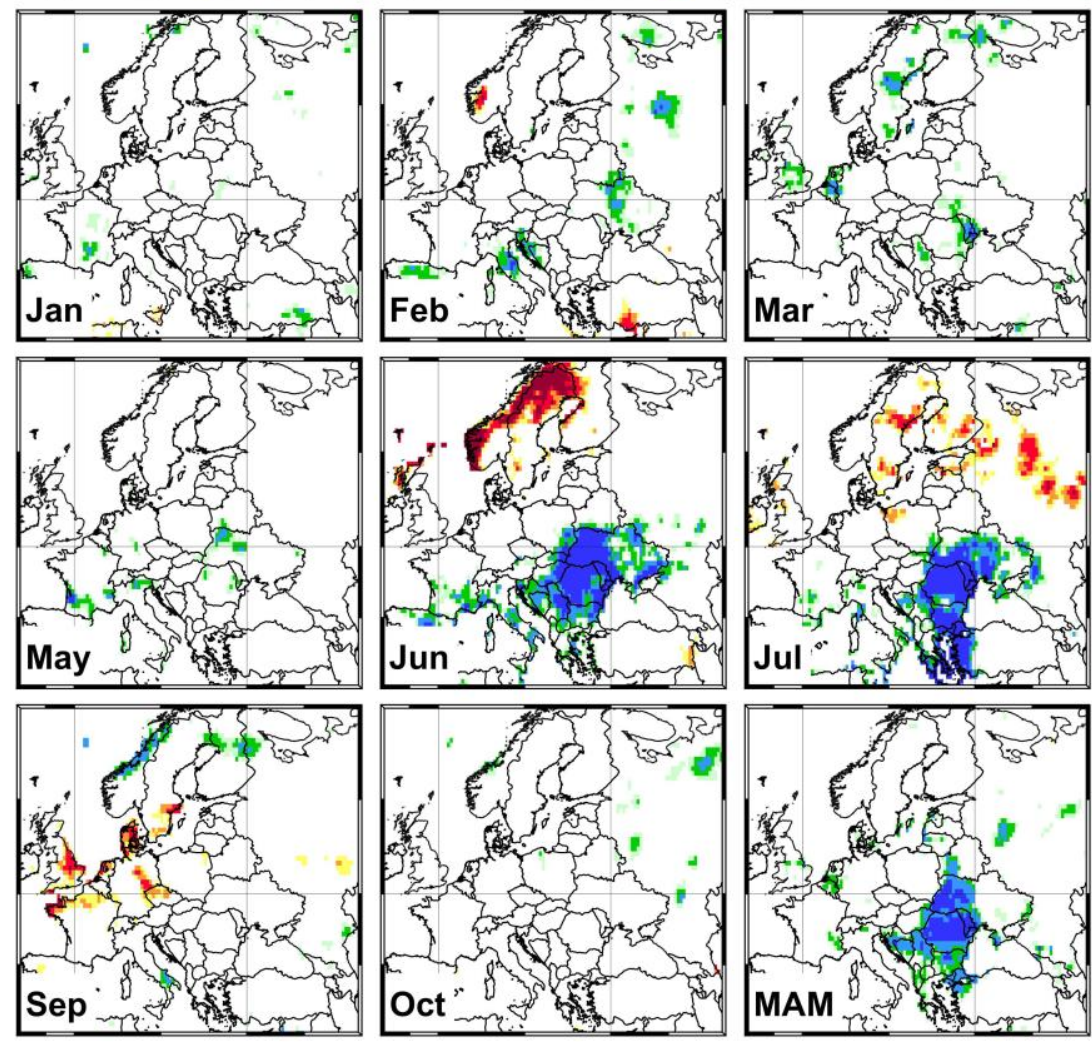

Figure 5. Stability map of the correlation between $\delta^{18} \mathrm{O}$ and CI from previous year September until current year October. Regions where the correlation is stable, positive and significant for at least $80 \%$ windows are shaded with dark red (95\%), red (90\%), orange (85\%) and yellow $(80 \%)$. The corresponding regions where the correlation is stable, but negative, are shaded with dark blue (95\%), blue (90\%), green (85\%) and light green (80\%). SEP - September previous year, OCT - October previous year, NOV - November previous year, DEC - December previous year, Jan - January, Feb - February, Mar - March, Apr - April, May May, Jun - June, Jul - July, Aug - August, Sep - September, Oct - October, MAM - march/April/May and JJA - June/July/August. Analyzed period: $1902-2012$ 
(a)

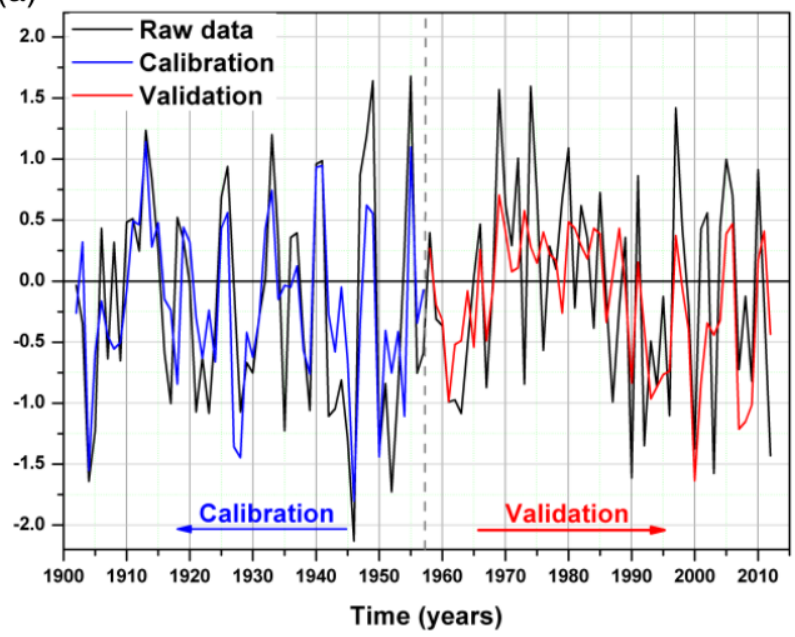

(c)

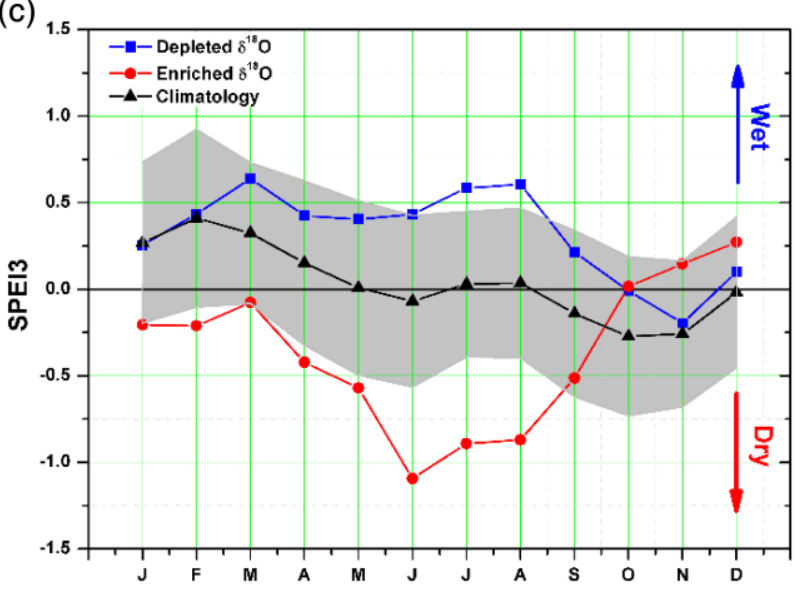

(b)

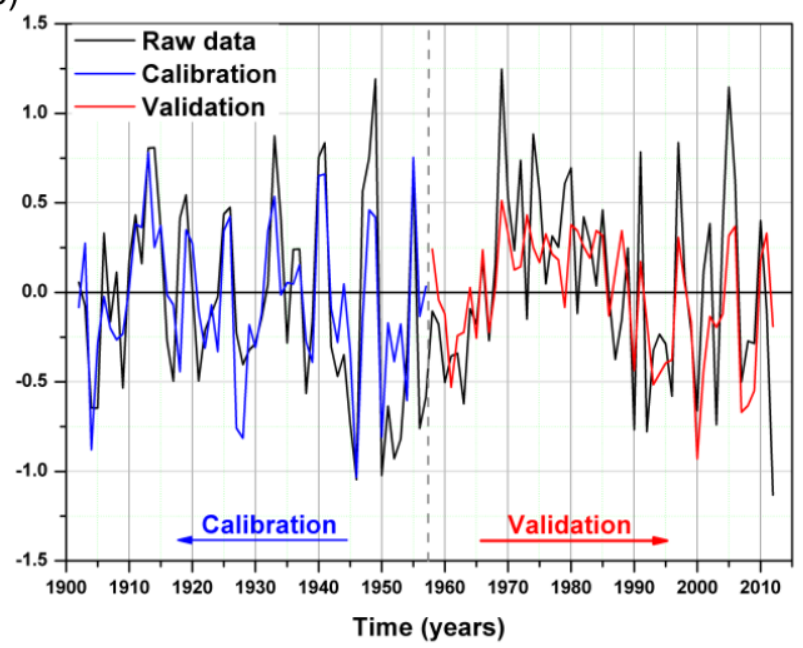

(d)

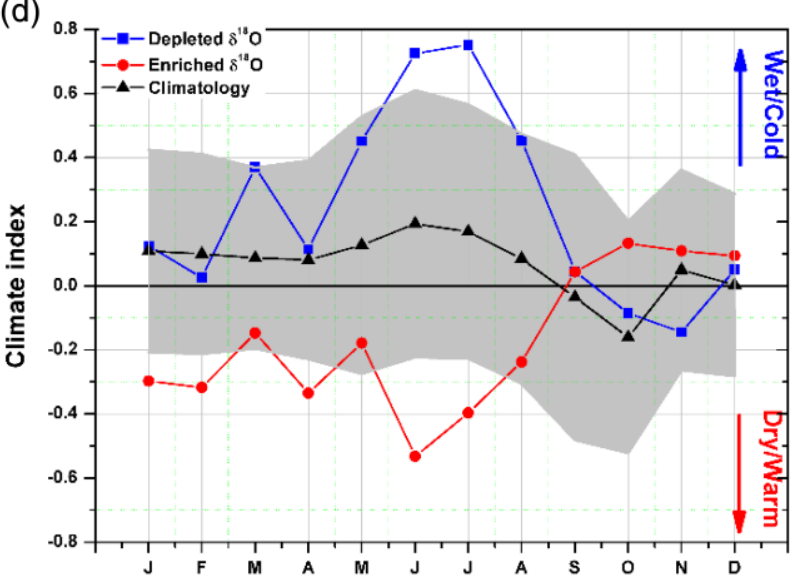

Figure 6. a) Calibration-verification model for a) August SPEI3; b) for CI JJA; c) the seasonal cycle for August SPEI3 during years with extreme $\delta^{18} \mathrm{O}$ values and d) the seasonal cycle for JJA CI during years with extreme $\delta^{18} \mathrm{O}$. In a) and b) the black line indicates the observed data; the blue line indicates the reconstructed SPEI3 (CI) for the calibration period and the red line indicates the reconstructed SPEI3 (CI) for the verification period. Where the coloured lines lie outside the grey shading, deviations higher/smaller than 1 standard deviation from average conditions occur. Analyzed period: $1902-2012$. 
(a)

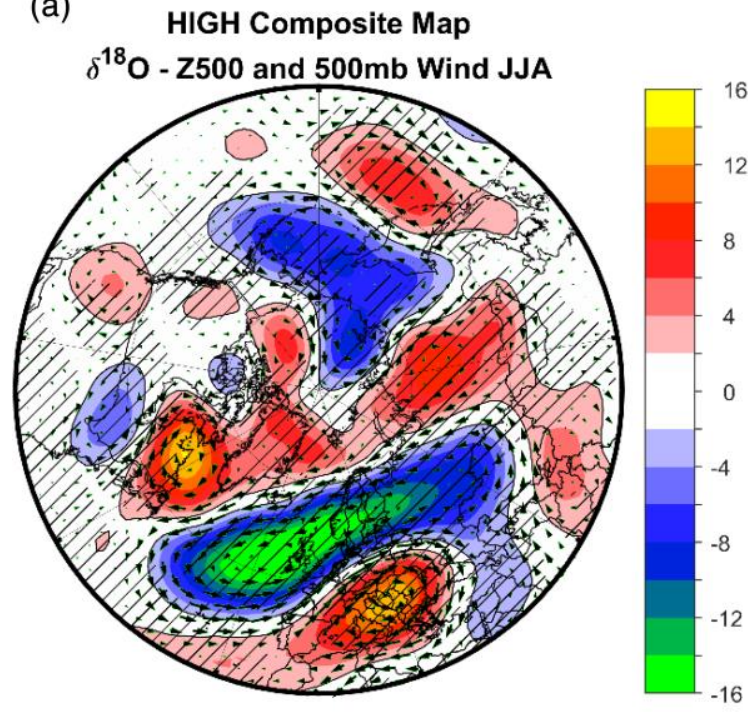

HIGH Composite Map

(c)

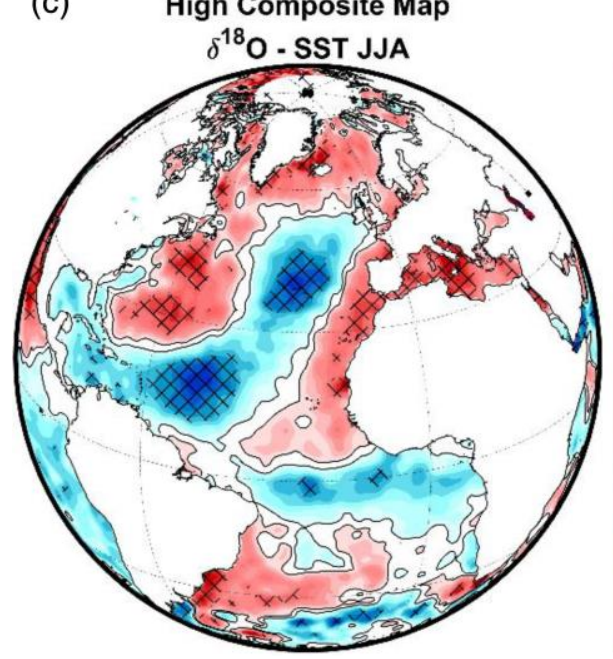

(b)

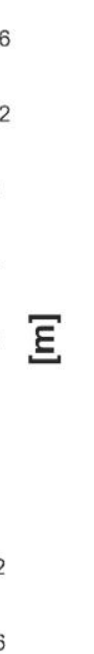

791

Figure 7. a) The composite map between low $\delta^{18} \mathrm{O}(<-1$ std. dev.) and summer Geopotential Height at

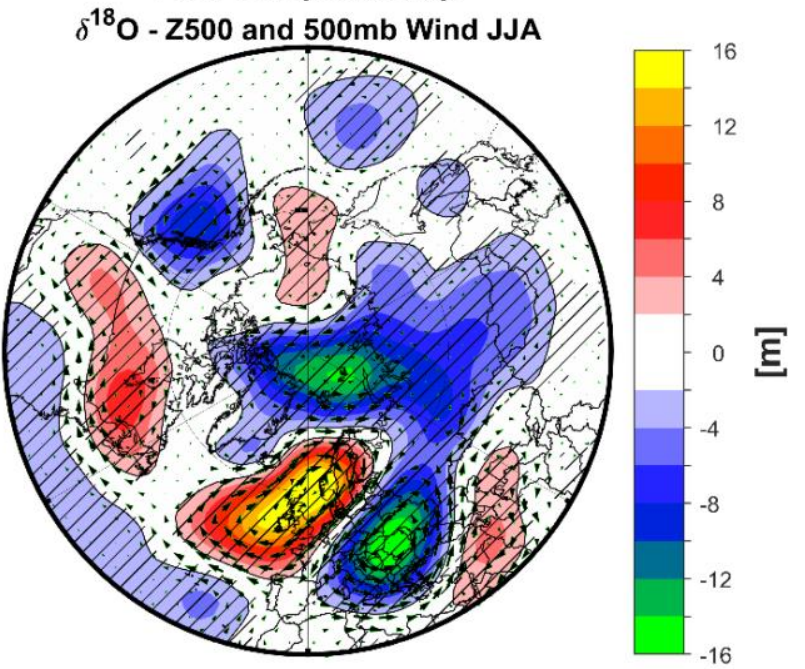

(d)
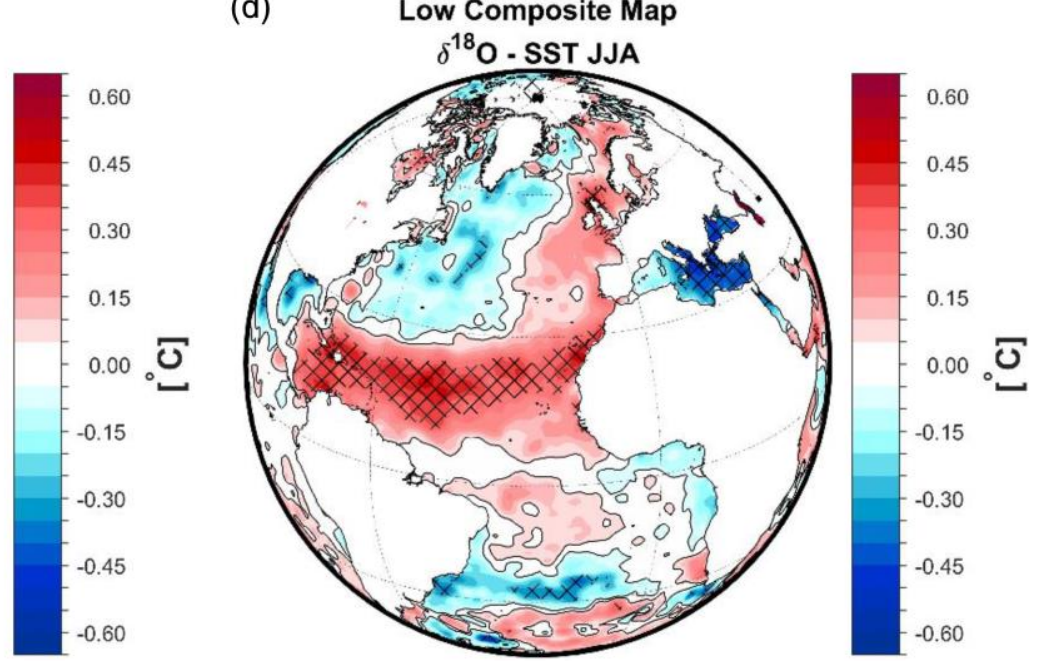
$500 \mathrm{mb}$ (Z500 — shaded colored areas) and summer $500 \mathrm{mb}$ wind vectors (black arrows); b) the composite map between high $\delta^{18} \mathrm{O}$ (> 1 std. dev.) and summer geopotential height at $500 \mathrm{mb}$ (Z500 — shaded areas) and summer $500 \mathrm{mb}$ wind vectors; c) as in a) but for the summer sea surface temperature (SST) and d) as in b) but for the summer sea surface temperature (SST). The hatching highlights significant values at a confidence level of $95 \%$. Analyzed period: 1876 - 2012. 